\title{
Complete recovery from anxiety disorders following Cognitive Behavioural Therapy in children and adolescents: a meta analysis
}

\section{Article}

Accepted Version

Creative Commons: Attribution-Noncommercial-No Derivative Works 4.0

Warwick, H., Reardon, T., Cooper, P., Murayama, K., Reynolds, S., Wilson, C. and Creswell, C. (2017) Complete recovery from anxiety disorders following Cognitive Behavioural Therapy in children and adolescents: a meta analysis. Clinical Psychology Review, 52. pp. 77-91. ISSN 0272-7358 doi: https://doi.org/10.1016/j.cpr.2016.12.002 Available at https://centaur.reading.ac.uk/68500/

It is advisable to refer to the publisher's version if you intend to cite from the work. See Guidance on citing.

To link to this article DOI: http://dx.doi.org/10.1016/j.cpr.2016.12.002

Publisher: Elsevier

All outputs in CentAUR are protected by Intellectual Property Rights law, including copyright law. Copyright and IPR is retained by the creators or other copyright holders. Terms and conditions for use of this material are defined in the End User Agreement. 


\section{CentAUR}

Central Archive at the University of Reading

Reading's research outputs online 
Complete recovery from anxiety disorders following Cognitive Behavior Therapy in children and adolescents: A meta-analysis

Helen Warwick ${ }^{\mathrm{a}}$, Tessa Reardon ${ }^{\mathrm{a} *}$, Peter Cooper $^{\mathrm{a}}{ }^{\mathrm{c}}$, Kou Murayama $^{\mathrm{a}}$, Shirley Reynolds ${ }^{\mathrm{a}}$, Charlotte Wilson ${ }^{\mathrm{d}}$, Cathy Creswella

a School of Psychology and Clinical Language Sciences, University of Reading, UK

${ }^{\mathrm{b}}$ Department of psychology, Stellenbosch University, South Africa

${ }^{c}$ Department of Psychology, University of Cape Town, South Africa

${ }^{\mathrm{d}}$ Department of Psychology, Trinity College, Dublin, Ireland

*Corresponding author:

Tessa Reardon

School of Psychology and Clinical Language Sciences

University of Reading

Whiteknights

Reading

Berkshire

UK

RG6 6AL

Telephone: $+44(0) 1183788523$

Email: t.c.reardon@pgr.reading.ac.uk 


\begin{abstract}
Cognitive Behavior Therapy (CBT) is a well-established treatment for childhood anxiety disorders. Meta-analyses have concluded that approximately $60 \%$ of children recover following treatment, however these include studies using a broad range of diagnostic indices to assess outcomes including whether children are free of the one anxiety disorder that causes most interference (i.e. the primary anxiety disorder) or whether children are free of all anxiety disorders. We conducted a meta-analysis to establish the efficacy of CBT in terms of absence of all anxiety disorders. Where available we compared this rate to outcomes based on absence of primary disorder. Of 56 published randomized controlled trials, 19 provided data on recovery from all anxiety disorders $(n=635$ CBT, $n=450$ control participants). There was significant heterogeneity across those studies with available data and full recovery rates varied from 47.6 to $66.4 \%$ among children without autistic spectrum conditions (ASC) and 12.2 to $36.7 \%$ for children with ASC following treatment, compared to up to $20.6 \%$ and $21.3 \%$ recovery in waitlist and active treatment comparisons. The lack of consistency in diagnostic outcomes highlights the urgent need for consensus on reporting in future RCTs of childhood anxiety disorders for the meaningful synthesis of data going forwards.
\end{abstract}

Words: 197

Keywords: Cognitive Behavior Therapy; Anxiety; Child 


\section{Introduction}

Anxiety disorders are among the most common mental health disorders experienced by children and young people, with an estimated prevalence of 6.5\% (Polanczyk, Salum, Sugaya, Caye \& Rohde, 2015). As well as having an impact on children's social and academic functioning (Woodward \& Fergusson, 2001), if left untreated, anxiety disorders often continue into adulthood and also present a risk for other mental health problems (Pine, Cohen, Gurley, Brook \& Ma, 1998). The most frequently evaluated psychological treatment for anxiety disorders in children and young people is Cognitive Behavior Therapy (CBT), and in recent years there have been a number of systematic reviews and meta-analyses examining the efficacy of this approach (e.g. Cartwright-Hatton, Roberts, Chitsabesan, Fothergill \& Harrington, 2004; Compton et al., 2004; Davis, May \& Whiting, 2011; In-Albon \& Schneider, 2007; Ishikawa, Okajima, Matsuoka \& Sakano, 2007; James, Soler \& Weatherall, 2005; James, James, Cowdrey, Soler \& Choke, 2013; Silverman, Pina \& Viswesvaran, 2008). These reviews have most commonly evaluated outcomes of CBT for mixed childhood anxiety disorders, typically including children presenting with social anxiety disorder, generalized anxiety disorder, and separation anxiety disorder. It has consistently been concluded that CBT shows clear benefit over a wait-list control, with, for example, an overall response rate of $59.4 \%$ for CBT versus $17.5 \%$ for controls (James et al., 2013).

While the outcomes from CBT for childhood anxiety disorders appear promising, a major limitation in meta-analyses conducted to date results from the lack of consistency in diagnostic outcomes reported across treatment trials. For example, while many trials report absence of the primary pre-treatment anxiety disorder diagnosis (i.e. the most impairing disorder) as their central outcome (e.g. Silverman et al., 1999; Spence, Donovan \& 
Brechman-Toussaint, 2000; Melfsen et al., 2011), others take more or less conservative approaches, including whether the initial primary disorder was still primary following treatment (e.g. Kendall et al., 1997), whether all the anxiety disorders that would have made the child eligible for inclusion were absent following treatment (e.g. Ginsburg et al., 2011), or whether the child had recovered from all anxiety disorder diagnoses (e.g. Cobham , 2012). The distinction between these indices of outcome is critical as comorbidity is common amongst children and young people with anxiety disorders (Waite \& Creswell, 2014). As such, it remains unclear from previous meta-analytic reviews what proportion of children continue to experience significant impairment due to anxiety following CBT. Indeed, it is perfectly possible that, many children who would be classed as 'recovered' on the basis of being free of their primary anxiety disorder following treatment would still actually meet the study inclusion criteria, highlighting the importance of considering diagnostic outcomes in relation to comorbid anxiety diagnoses as well as primary anxiety diagnoses.

The central aim of this meta-analysis is to establish the efficacy of CBT for childhood anxiety disorders in terms of absence of all anxiety disorders. To help determine whether outcomes classified in this way differ from alternative, less conservative outcomes, we also set out to compare 'complete recovery' rates with those based on being 'free of the primary anxiety disorder' where this was also reported. In keeping with the most recent Cochrane review of CBT for childhood anxiety disorders (James et al., 2013), we included randomized controlled trials in which treatment targeted anxiety disorders among children and adolescents, including those with autistic spectrum conditions (ASC) (James et al., 2013). However we conducted separate analyses on the basis of whether participants had an ASC on the basis that treatment protocols used in the context of ASC have typically been 
modifications of standard protocols (e.g. Wood et al.,2009) and the extent to which treatment effects generalize to comorbid disorders may be affected by the presence of ASC.

\section{Method}

The current review followed PRISMA guidelines (Moher, Liberati, Tetzlaff, \& Altman, 2009) and built on the recent Cochrane review (James et al., 2013) by adhering to the same procedures and by initially identifying studies included on the basis of their inclusion in that recent review. Further studies (post 2012) were located using a replication of the Cochrane search strategy and adapted for use across the individual databases - Psychinfo, Embase and Medline (see Appendix A for search strategy). These database searches were conducted independently by two reviewers (HW and GH) in April 2014. The searches were then rerun in March 2015 by HW and TR, to account for any additional studies published during the main data extraction phase.

\section{Criteria for study inclusion}

To be included in the meta-analysis, each study had to meet the criteria below. The criteria were based on those of the Cochrane review, with additional criteria to meet the aims of the current study (see $\mathrm{j}$ below) and for clarity (see k below).

a. Randomized controlled trial including cross-over trials and cluster-randomized trials

b. Used manualized and documented modular CBT

c. Involved direct contact with the child

d. CBT versus waiting list/ active control conditions/ TAU/ medication (not including other CBT groups)

e. Participants must have met the criteria of DSM or ICD for an anxiety diagnosis

f. Participants with diagnosis must be children and/or young people (between 4-19 years 
old)

g. All comorbidities allowable for anxiety disorders under the rules of DSM and ICD, such as ASC, intellectual impairment and physical disorders

h. All settings such as research settings (i.e. university outpatient clinics) inpatient services, community clinics, and schools

i. CBT delivered individually, in a group format or with family or parental involvement

j. Reported/provided number or percentage with/without any anxiety disorder diagnosis post treatment

k. Post-treatment data reported for both treatment and control groups.

James et al. (2013) included an additional requirement that studies involved 9 sessions or more of CBT. We removed this criterion as few relevant studies involved fewer than 9 sessions of individual child CBT and this criterion did not account for variations in session length (e.g. the application of fewer but longer treatment sessions). One study was excluded from James et al.'s review solely on the basis of this criteria (Gallagher, Rabian \& McCloskey, 2004) and, as detailed below, was therefore considered for inclusion in the current review.

\section{Exclusion criteria}

In line with James et al. (2013), studies that only included participants with simple phobias, PTSD, OCD or elective mutism were excluded.

\section{Study selection}

Studies considered for potential inclusion in the current review were identified through i) the Cochrane review; and ii) our updated searches replicating the Cochrane search 
strategy. Forty-one studies included in the Cochrane review, plus the one additional study using a brief intervention, were automatically taken to full paper screening to confirm eligibility. In total 2081 studies published since 2012 were identified through our updated database searches. Following the removal of duplicates, two raters (HW and GH) independently screened the remaining abstracts from our searches $(\mathrm{k}=1486)$ for inclusion or exclusion using the criteria detailed above. Any discrepancies between raters were reviewed by a third rater (CC) for the final decision. Seventy-four studies identified through our searches were taken to the full paper screening stage.

In total 116 full papers were independently assessed twice by either HW or TR and one of a further three raters (PC, SR, CW). Again any discrepancies were passed onto CC for further screening and a final decision.

Where inclusion was uncertain due to missing information, TR contacted study authors via email. After 2 weeks, authors were sent a reminder email. If authors did not respond within 4 weeks of the original request, or the data were unavailable, these studies were excluded from further analyses. For those where relevant data was provided, this was added to the overall data extracted for that study. The flow chart (Figure 1) highlights each stage of this process.

[Insert Figure 1 about here]

\section{Data collection}

A standard data extraction form was developed and piloted by one reviewer (HW). Two independent reviewers then completed the data extraction for all included studies (HW 
or TR; and either SR, CW or PC). Discrepancies in extracted data between the reviewers were passed to a third reviewer (CC) and a final decision was agreed. In addition to data provided in published papers, unpublished data from 7 studies was also provided by authors (including one in press manuscript, Silk et al., submitted), and these data were incorporated into the data extraction form.

\section{Data extraction variables}

The following data were extracted for descriptive purposes: participant numbers, age, and gender, presence of ASC, type of control, method of diagnostic assessment, degree of parental involvement (following Reynolds, Wilson, Austin \& Hooper, 2012), mode of delivery ('individual' or 'group'), treatment target ('disorder specific' or 'general anxiety'), treatment duration.

The primary outcome measure recorded was the number of participants free from all DSM-IV (or DSM-III) anxiety diagnoses post treatment (i.e. the number who were free from social phobia, separation anxiety disorder, generalized anxiety disorder/over anxious disorder, panic disorder with/out agoraphobia, agoraphobia, specific phobia, obsessive compulsive disorder, post-traumatic stress disorder, and anxiety disorder not otherwise specified). This number was recorded for each CBT-group and for the control group. If it was also reported (or provided) by authors, the number of participants free from their primary anxiety disorder post treatment was also recorded for each group separately (i.e. the number who no longer met diagnostic criteria for their pre-treatment primary anxiety disorder).

Some studies included follow-up assessments for both the CBT-treatment groups and the control group. In these cases, the number of participants free from all anxiety diagnoses 
was recorded for each CBT-treatment group and for the control group, together with the corresponding follow-up time period $(3,6,12$ or 24 months). The number of participants free from their primary anxiety diagnosis within each group was also recorded (where this information was available).

\section{Quality rating}

Following Reynolds et al. (2012), each paper was independently rated by two people (CW, SR) using a modified version of a 23 item quality coding system designed specifically to assess interventions for depression and 'neurosis' (Moncrieff, Churchill, Drummond \& McGuire, 2001). The scale reflects specific methodological issues associated with mental health treatment studies, and each item is rated on the basis of information provided in the published paper. Items are rated as 0 (absent), 1 (partially present), or 2 (fully present). Ratings of 0 (absent) and 2 (present) are used for dichotomous variables (e.g. ITT analysis). Items cover basic elements of study design (e.g. randomization method, sample selection, sample size), data analysis (e.g. intent to treat analyses), length of follow-up, and presentation of results. Higher total scores reflect better quality studies. We applied the same minor modifications to the coding scheme as in Reynolds et al. (2012) to reflect that fact that we were assessing psychotherapy studies. Specifically, we did not code the item relating to blinding participants to treatment allocation as this is not possible in studies of psychotherapy. In addition we added two new items to indicate if therapy was manualized (1 - yes, 0 - not manualized $)$ and if therapy integrity was tested $(1-$ yes, 0 - no assessment of treatment integrity).

In the current study inter-rater reliability of quality was good $(\mathrm{ICC}=.77$, mean item kappa $=.67)$. With the exception of one item, there was at least a_moderate level of 
agreement between raters across individual items (kappa range .17-1.00). All discrepancies were discussed between the two raters to reach consensus.

\section{Meta analytic method}

A random effects model was used for each meta-analysis to reflect the varied populations included in the review. As the primary outcome variable provides dichotomous data (free from all anxiety diagnoses or not), the log odds ratio (Log OR) and 95\% confidence interval (CI) were calculated. Log OR were calculated using the following formula: $\log (\mathrm{n} 1 / \mathrm{n} 2) /(\mathrm{n} 3 / \mathrm{n} 4)($ where $\mathrm{n} 1=$ number free from all anxiety diagnoses in the CBT group; $\mathrm{n} 2=$ number free from all anxiety diagnoses in the control group; $\mathrm{n} 3=$ number not free from all anxiety diagnoses in the CBT group; $\mathrm{n} 4=$ number not free from all anxiety diagnoses in the control group). Pooled data were also used to calculate the proportion of participants who recovered in each group. In studies with more than one CBT group, each CBT group was included as a separate comparison with the same control group in the analysis. All analyses were based on an intent-to-treat (ITT) model. The Q-statistic was used to test for heterogeneity across studies. ' $\mathrm{R}$ ' and the associated 'metafor' package were used to conduct all analyses.

Post-treatment primary outcome data were pooled and meta-analyses were run to compare treatment effectiveness in the following sub-groups: (i) CBT vs wait list in samples without ASC; (ii) CBT vs active control in samples without ASC; (iii) CBT vs wait list in samples with ASC; (iv) CBT vs active control in samples with ASC. Further meta-analyses examining recovery in relation to primary anxiety disorders and recovery at follow-up were planned if sufficient data were available. 


\section{Results}

\section{Description of included studies}

In total, 19 studies (described in 20 papers) were included, with a total of 635 CBT participants and 450 control participants. Details of excluded studies are provided in Appendix B and reasons for exclusion are listed in Figure 1. The most frequent reason for exclusion was a lack of available data on the number of participants free from all anxiety disorders post-treatment (29 studies).

Characteristics of included studies are provided in Table 1. Fourteen studies included samples of children/adolescents without ASC and five included samples with ASC. Among studies of children without ASC, 9 studies compared a CBT intervention to a wait-list control. Two of these studies included two CBT groups (Barrett, Dadds \& Rapee ,1996, Barrett, 1998) - a child-only treatment group and a family-treatment group. Across these 11 CBT-wait list comparisons (from 9 studies), eight involved parents in all or nearly all sessions (Barrett et al., 1996; Barrett. 1998; Chiu et al., 2013; Cobham, 2012; HirshfeldBecker et al., 2010; Shortt, Barrett \& Fox, 2001; Spence, Holmes, March \& Lipp, 2006; Waters, Ford, Wharton \& Cobham, 2009), one involved parents in some sessions (Dadds, Spence, Holland, Barrett \& Laurens, 1997) and two had no parent involvement (Barrett et al, 1996; Barrett ,1998). The CBT treatment was delivered individually to children/families in five (Barrett et al., 1996 (child), Barrett et al., 1996 (family), Chiu et al., 2013; Cobham, 2012; Hirshfeld-Becker et al., 2010) and in groups in six of the CBT-wait list comparisons (Barrett, 1998 (child), Barrett, 1998 (family), Dadds et al., 1997; Shortt et al., 2001; Spence et al., 2006; Waters et al., 2009). The number and length of treatment sessions varied considerably across these studies, but no study involved less than 10 hours of treatment. All of the studies comparing CBT to a wait-list in non-ASC samples involved children under 14 
years, with five studies of 7-14 year olds (Barrett et al., 1996; Barrett, 1998; Cobham, 2012; Spence et al., 2006; Dadds et al., 1997 ) and four studies including younger children (6.5-10 year olds, Shortt et al., 2001; 5-12 year olds, Chiu et al., 2013; 4-8 year olds, Waters et al., 2009; 4-7 year olds, Hirschfeld-Becker et al., 2010).

Five studies of children without ASC compared a CBT intervention with another treatment: treatment as usual (Barrington, Prior, Richardson \& Allen, 2005), attention control or attention support (Ginsburg \& Drake, 2002; Hudson et al., 2009; Masia-Warner, Fisher, Shrout, Rathor \& Klein,2007), and a non-CBT active treatment (Silk et al., submitted). Among these five active-control studies, one did not involve parents in treatment sessions (Ginsburg \& Drake, 2002), two had minimal parental involvement (Masia-Warner et al., 2007; Silk et al., submitted) and two had significant parent involvement (Barrington et al., 2005; Hudson et al., 2009). Treatment was delivered individually in two studies (Silk et al., submitted; Barrington et al., 2005) and in groups in three (Masia-Warner et al., 2007; Hudson et al., 2009; Ginsburg \& Drake, 2002). The minimum total treatment time was 7.5 hours (Ginsburg \& Drake, 2002). The age range of children in these CBT-active control comparisons varied, with two studies focusing on adolescents (14-16 year olds, MasiaWarner et al., 2007; 14-17 year olds, Ginsburg \& Drake, 2002) and three studies including children and adolescents (7-14 year olds, Barrington et al., 2005; 7-16 year olds, Hudson et al., 2009; 9-14 year olds, Silk et al., submitted).

Among the five studies of children/adolescents with ASC, two compared CBT with a wait-list control (Chalfant, Rapee \& Carroll,2007; McConachie et al., 2014) and three compared CBT with treatment as usual (Reaven, Blakeley-Smith, Culhane-Shelburne \& Hepburn, 2012; Storch et al., 2013; Storch et al., 2015). The CBT treatment was delivered in 
group sessions in three ASC studies (Chalfant et al., 2007; McConachie et al., 2014; Reaven et al., 2012), and individually in the remaining two (Storch et al., 2013, Storch et al., 2015), with significant parent involvement across all ASC studies. Treatment duration in ASC studies varied from 14 hours (McConachie et al., 2014) to 24 hours (Chalfant et al., 2007). One study with an ASC sample focused on adolescents (11-16 years olds; Storch et al., 2015), one focused on 7-11 year olds (Storch et al., 2013) and the others included children and young adolescents (8-13 year olds, Chalfant et al., 2007; 9-13 year olds McConachie et al., 2014;7-14 year olds, Reaven et al., 2012).

\section{[Insert Table 1 about here]}

\section{Primary outcome: free from all anxiety diagnoses}

Table 2 details the number and proportion of participants free from all anxiety diagnoses post-treatment across all studies.

\section{Studies of children/adolescents without ASC.}

Eleven CBT vs wait-list comparisons were included in the meta-analysis examining recovery from all anxiety diagnoses among non-ASC samples. This analysis included 321 CBT participants and 210 wait-list control participants. 66.4\% (95\% CI 56.6-76.1) CBT participants were free from all anxiety diagnoses post treatment, compared with $20.6 \%$ (95\% CI 11.8-29.5) of wait-list controls (Log OR 1.95, 95\% CI 1.25-2.64, p<0.001). Figure 2 illustrates the benefit of CBT compared with wait-list reported across the majority of these studies. The Q-test provided evidence of heterogeneity across these studies $(\mathrm{Q}=25.69, \mathrm{df}=$ $10, \mathrm{p}<0.01)$. 
Five studies were included in the analysis examining recovery from all anxiety diagnoses following CBT compared with an active control. 205 CBT participants and 144 control participants were included in this meta-analysis, and $47.6 \%$ (95\% CI 33.4-61.6) CBT participants were free from all anxiety diagnoses post treatment, compared with $21.3 \%$ (95\% CI 3.8-38.7) active control participants ( $\log$ OR $0.83,95 \%$ CI $0.32-1.33, \mathrm{p}<0.01)$. The Qtest did not provide evidence of heterogeneity across these studies $(Q=5.2, d f=4, p=0.27)$. As shown in Figure 3, however, the Log OR crossed 0 for all but one CBT-active control comparison.

\section{[Insert Figure 3 about here]}

Combining 526 CBT participants without ASC included in both CBT vs wait-list comparisons and CBT vs active control comparisons, indicated that in total 60.7\% (95\% CI 51.8-69.6) were free from all anxiety diagnoses post-treatment.

\section{Studies of children/adolescents with ASC.}

Two studies of children/adolescents with ASC were included in the meta-analysis to examine recovery from all anxiety diagnoses following CBT compared with a wait-list control. 45 CBT participants and 34 wait-list control participants were included in the analysis, but no significant differences between the groups was found (Log OR 2.42, 95\% CI $-2.14-6.97, \mathrm{p}=0.30)$. Pooling the results of these two studies indicated that $36.7 \%(95 \% \mathrm{CI}$ crosses 0\%) CBT participants were free from all anxiety diagnoses post treatment, compared with $2.7 \%$ (95\% CI crosses $0 \%$ ) wait-list participants (see Figure 4 for forest plot). The Q-test 
did not provide evidence of heterogeneity across these two studies $(\mathrm{Q}=3.43$, $\mathrm{df}=1, \mathrm{p}=$ $0.06)$.

\section{[Insert figure 4 about here]}

The analysis comparing recovery from all anxiety diagnoses following CBT compared to an active control among ASC samples included 3 studies (64 CBT participants, 62 active control participants). Again, no significant differences were found between the groups (Log OR 1.39, 95\% CI -0.28-3.06, p = 0.10). In these ASC samples, $12.2 \%(95 \% \mathrm{CI}$ crosses $0 \%$ ) of CBT participants and $2.7 \%$ (95\% CI crosses $0 \%$ ) of control participants were free from all anxiety diagnoses post treatment. As illustrated in the Figure 5, the Log OR CI for each study crossed 0 . The Q-test did not provide evidence of heterogeneity across these studies $(\mathrm{Q}=1,2, \mathrm{df}=2, \mathrm{p}=0.54)$.

\section{[Insert Figure 5 about here]}

Combining 109 CBT participants with ASC included in both the CBT-wait-list and CBT-active control comparisons indicated that in total $23.2 \%$ (95\% CI crosses $0 \%$ ) were free from all anxiety diagnoses post-treatment.

\section{Secondary outcomes}

As detailed in Table 2, post-treatment recovery data in relation to primary anxiety diagnoses were only available for 9 studies ( 5 studies of non-ASC samples and 4 studies of ASC samples). Given the small number of CBT vs wait-list and CBT vs active control within each category of sample-type (i.e. among children/adolescents with ASC and among 
children/adolescents without ASC), these meta-analyses were not run. Combining 138 CBT participants without ASC included in both the CBT-wait-list and CBT-active control comparisons with recovery data relating to both primary diagnoses and all anxiety diagnoses indicated that in total 50.2\% (95\% CI 39.5-60.8) were free from primary anxiety diagnosis post treatment compared with $42.1 \%$ (95\% CI 29.8-54.3) free from all anxiety diagnoses.

Similarly, combining 81 CBT participants with ASC included in both the CBT-waitlist and CBT-active control comparisons with recovery data relating to both primary diagnoses and all anxiety diagnoses, indicated that in total $23.7 \%$ (95\% CI 6.0-41.3) were free from primary anxiety diagnosis post treatment compared with $7.8 \%$ (95\% CI crosses $0 \%$ ) free from all anxiety diagnoses.

Five studies provided follow-up data, including a 3 month follow-up (Hudson et al., 2009), 6 month (Masia-Warner et al., 2007), 12 month (Silk et al., submitted), and multiple follow-ups (Barrington et al., 2005; Dadds et al., 1997 and Dadds et al. 1999). Given the lack of data for any single follow-up period, we did not include these data in the meta-analysis

\section{Discussion}

In the last 20 years there has been rapid growth in the number of randomized controlled trials that have evaluated outcomes following CBT for anxiety disorders in children and adolescents. Our review highlights the lack of consistency in diagnostic outcomes used in these trials. Previous reviews and meta-analyses have typically included the primary outcome that was reported in each trial, but in some trials this reflects, for example, whether the child is free of the most interfering anxiety disorder while in others it reflects whether the child is free of all anxiety disorder diagnoses. We identified that of 56 randomized controlled trials that include child-focused CBT, 19 provided (or made available) 
data on whether participants were free of all anxiety disorders. Thus, although complete recovery from all anxiety disorders is assessed and reported in a sizeable minority of trials, this data was not available for many trials. In many cases, where trials were open to children and adolescents with any anxiety disorder, this means that it is unclear how many participants, following treatment, would still fulfil criteria for inclusion in the trial. We also note wide variation in outcomes across studies on the basis of whether participants are free of all anxiety disorders. This is demonstrated by the significant heterogeneity in our largest comparison (non-ASC, CBT versus wait-list) and also in the fact that CBT (non ASC) was associated with $66.4 \%$ recovery from all diagnoses in one set of comparisons and $47.6 \%$ in another. A smaller number of studies with ASC than non-ASC populations were identified, but a similar pattern was found, i.e. that the number of children who were free of all anxiety diagnoses following CBT varied substantially across comparisons from $36.7 \%$ to $12.2 \%$.

Also of note, and out of kilter with previous reviews (e.g. James et al., 2013), was that the average rate of recovery from all diagnoses was very similar in the wait-list (20.6\%) and active comparison $(21.3 \%)$ groups.

Overall recovery rates from all anxiety disorders following CBT for child anxiety disorders was $60.7 \%$ for non ASC and $23.2 \%$ for ASC populations. While these outcomes are based on a conservative index of outcome and may appear to be worth celebrating (at least within non ASC populations), there was wide variability in findings across comparisons. As such the main conclusion to be drawn from this review is that, in order to produce consistent information from treatment trials for child anxiety disorders and information that would be available for meaningful synthesis, there is an urgent need for a consensus and established guidelines on how diagnostic information should be used in reporting outcomes. 
The small number of studies that provided data on recovery from all anxiety diagnoses precluded further analyses that would have been of interest. For example, the small number of studies limits firm conclusions about the comparative outcomes of those with ASC and those without the condition. Nevertheless, it is striking to note that recovery from all anxiety diagnoses was substantially lower in the former group (23.2\%) than the latter $(60.7 \%)$. This pattern of results is contrary to the conclusion drawn in the recent Cochrane review that 'CBT is particularly effective for children and adolescents with ASD' (James et al., 2013; p 27).

Furthermore we were limited in the extent that we could draw conclusions regarding the comparative outcomes for 'free of all anxiety disorders' and 'free of primary disorder'. Only 5 studies with non-ASC and 4 with ASC populations provided information on outcomes in relation to both all diagnoses and the primary diagnosis. However, unsurprisingly, more children were free of their primary disorder (non ASC 50.2\%; ASC 23.7\%) than all disorders (non-ASC 42.1\%; ASC 7.8\%). We were also unable to examine moderators of treatment outcome (as in e.g. Reynolds et al., 2012). This was unfortunate as it is possible that the generalization of treatment effects may be more or less likely to happen under certain conditions (e.g. in older/younger children, with generic/disorder specific treatment protocols, in group/individual formats, with/out parent involvement). Indeed, there was wide variation among the included studies in relation to what data was collected on these factors. It is equally plausible that the number and severity of pre-treatment anxiety diagnoses, or the presence of other non-anxiety comorbid conditions, influence full recovery rates, but again due to variation in reporting of this data across studies, we were not able to examine the role of these pre-treatment clinical characteristics. Similarly, demographic characteristics (e.g. 
ethnicity and socio-economic status) were not consistently reported across studies, precluding us from drawing conclusions about treatment outcomes among different ethnic/socioeconomic groups._There is some evidence, for example, that anxiety-focused CBT is effective among children/adolescents from different ethnic groups (Ginsburg \& Drake 2002; Silverman et al. 1999); although, factors that may moderate treatment outcomes among minority ethnic groups, such as level of acculturation (Pine \& Silverman 2004), remain to be established. It is therefore important that researchers prioritise reporting detailed sample characteristics in the future, thereby enabling findings to be combined across studies and potential moderators of treatment outcome to be fully examined. Finally, there was very little follow-up data beyond the end of treatment, and where there was follow-up data (5 studies), there was wide variation in the follow-up period. Given that CBT treatments are often relatively short, it is plausible that treatment might focus on the more severe or impairing disorder and we might therefore initially see most dramatic change in that primary disorder; but with time positive effects may generalize to other comorbid difficulties (e.g. Ollendick, Ost, Reuterskiold \& Costa, 2010). This issue will be important to address as more long-term follow-up data accumulate, as will the possibility that particular treatment formats might promote generalization more than others. The ability to address these issues relies on consistent reporting of comparative diagnostic outcomes that consider both comorbid anxiety diagnoses as well as primary diagnoses post-treatment and at follow-up.

Other limitations of the available data include the fact that few studies included young people over 14 years or under 7 years of age. Indeed none of the wait-list comparison studies with non-ASC populations included young people over the age of 14 years, and mean ages were typically 10 years or younger. Due to the small number of studies we combined 'active' comparisons. In many cases the 'active' control aimed to control for therapist attention and 
did not constitute a bona-fide treatment that would be delivered in 'real-world' settings (e.g. Hudson et al., 2009), but in some the comparator was 'treatment as usual' (e.g. Barrington et al., 2005; Storch et al., 2013; Storch et al., 2015; Reaven et al., 2012) or a standardized alternative treatment (Child Centred Therapy; Silk et al., submitted). These different active controls are extremely unlikely to be equivalent, and so forming a single comparison group of 'active controls' is a clear limitation. It is also of note that none of the included studies compared CBT to medication. Like James et al. (2013) all of the included studies included community or outpatient participants, and none included those receiving day patient or inpatient treatment who are likely to be those most severely affected. Finally, although the majority of studies used one diagnostic interview (ADIS-c/p) there was variability in how it was administered, with some using both child and parent report, and others using one or the other. This variability applied equally to studies which reported recovery from all and/ or primary anxiety disorders.

Quality ratings of included studies ranged from 23 to 36 of a possible 44 . Strengths that were present in most studies included good descriptions of treatment, the use of treatment manuals and assessments of treatment integrity, and also good descriptions of outcome measures. Many studies analyzed the data thoroughly and drew appropriate conclusions. However, there were also common weaknesses both in study design and reporting. Sample sizes were typically small and rarely representative. Furthermore, many studies did not set a priori hypotheses, preferring more open aims. Many studies reported minimal demographic information and poor information about the concealment of randomisation. One important omission was that none of the studies reported any adverse events or side effects. Studies rated as better quality had few weaknesses, tending to have a 
small sample size and not reporting side effects. Poorer quality studies had a wider range of omissions, and often partially met criteria rather than fully meeting them.

In line with other meta-analyses we focussed on the traditional delivery format for CBT for childhood anxiety disorders, i.e. child-focussed (with or without parent involvement). The findings cannot therefore be generalized to other emerging delivery formats, such as where parents are guided in the application of CBT principles with their child (e.g. Cartwright-Hatton et al., 2011), often in a low intensity format (e.g. Lyneham \& Rapee, 2006; Thirlwall et al., 2013; Cobham, 2012). As noted above it is plausible that where parents are supported in implementing strategies in the home there may be more scope for generalization of treatment effects, so it will be important that future reviews consider these alternative formats as more studies emerge. It is also important to note that we considered two commonly used diagnostic outcomes, however alternative diagnostic outcomes have been used and should be considered when drawing a consensus on reporting in future trials. For example, in the CAMS trial diagnostic outcomes were based on whether children still met criteria for the three diagnoses which were considered for eligibility in the trial (Ginsburg et al., 2011). Finally, we have focused on measures of diagnostic outcomes, however, the importance of reaching a consensus on reporting in future trials also applies to other types of treatment outcome (e.g. continuous measures of anxiety symptoms and interference).

\section{Conclusions}

Clinician rated diagnostic measures are often considered the 'gold-standard' for assessing treatment outcomes in randomized controlled trials of CBT for anxiety disorders in children and adolescents. However published trials have not been consistent in the way in which these diagnostic data have been used. This variation in reporting has substantial 
implications for what can be derived from each trial and creates difficulties in synthesizing data across trials. Only a minority of current published trials (19/56) provided data on whether children and young people had made a full recovery from all anxiety disorders; and, of those, few also provided data on whether participants were free of their primary diagnosis. We have highlighted the potential benefit of considering comparative measures of diagnostic outcome, including both primary diagnoses together with a more conservative index that extends beyond primary diagnoses, such as recovery from all anxiety diagnoses. However, most importantly, before meaningful conclusions can be drawn, it is essential that clinicians and experts in the field reach a consensus and develop guidance on which outcomes should uniformly be presented across treatment trials for childhood anxiety disorders. 


\section{Acknowledgements}

The authors thank Georgia Halls and Liz White for their contributions to this manuscript. CC is funded by an NIHR Research Professorship (NIHR-RP-2014-04-018). 


\section{References}

Barrett, P. M. (1998). Evaluation of cognitive-behavioral group treatments for childhood anxiety disorders. Journal of Clinical Child Psychology, 27, 459-468. doi: 10.1207/s15374424jccp2704_10

Barrett, P. M., Dadds, M.R. \& Rapee, R. M. (1996). Family treatment of childhood anxiety: A controlled trial. Journal of Consulting and Clinical Psychology, 64(2), 333-342. doi: 10.1037/0022-006x.64.2.333

Barrington, J., Prior, M., Richardson, M. \& Allen, K. (2005). Effectiveness of CBT versus standard treatment for childhood anxiety disorders in a community clinic setting. Behaviour Change, 22, 29-43. doi: 10.1375/bech.22.1.29.66786

Cartwright-Hatton, S., McNally, D., Field, A. P., Rust, S., Laskey, B., Dixon, C....Woodham, A. (2011). A new parenting-based group intervention for young anxious children: Results of a randomized controlled trial. Journal of the American Academy of Child and Adolescent Psychiatry, 50, 242-251. doi: 10.1016/j.jaac.2010.12.015

Cartwright-Hatton, S., Roberts, C., Chitsabesan, P., Fothergill, C. \& Harrington, R. (2004). Systematic review of the efficacy of cognitive behaviour therapies for childhood and adolescent anxiety disorders. British Journal of Clinical Psychology, 43, 421-436. doi: $10.1348 / 0144665042388928$

Chalfant, A. M., Rapee, R. \& Carroll, L. (2007). Treating anxiety disorders in children with high functioning autism spectrum disorders: A controlled trial. Journal of Autism and Developmental Disorders, 37, 1842-1857. doi: 10.1007/s10803-006-0318-4

Chiu, A. W., Langer, D. A., McLeod, B. D., Har, K., Drahota, A., Galla, B. M., Jacobs, J., Ifekwunigwe, M. \& Wood, J. J. (2013). Effectiveness of modular CBT for child anxiety in elementary schools. School Psychology Quarterly, 28, 141-153. doi: $10.1037 /$ spq0000017 
Cobham, V. E. (2012). Do anxiety-disordered children need to come into the clinic for efficacious treatment? Journal of Consulting and Clinical Psychology, 80, 465-476. doi: $10.1037 / \mathrm{a} 0028205$

Compton, S. N., March, J. S., Brent, D., Albano, A. M., Weersing, V. R. \& Curry, J. (2004). Cognitive-behavioral psychotherapy for anxiety and depressive disorders in children and adolescents: An evidence-based medicine review. Journal of the American Academy of Child \& Adolescent Psychiatry, 43, 930-959. doi:

10.1097/01.chi.0000127589.57468.bf

Dadds, M. R., Holland, D. E., Laurens, K. R., Mullins, M., Barrett, P. M. \& Spence, S. H. (1999). Early intervention and prevention of anxiety disorders in children: Results at 2-year follow-up. Journal of Consulting and Clinical Psychology, 67, 145-150. doi: 10.1037//0022-006x.67.1.145

Dadds, M. R., Spence, S. H., Holland, D. E., Barrett, P. M. \& Laurens, K. R. (1997). Prevention and early intervention for anxiety disorders: A controlled trial. Journal of Consulting and Clinical Psychology, 65, 627-635. doi: 10.1037//0022-006x.65.4.627

Davis, T. E., May, A. \& Whiting, S. E. (2011). Evidence-based treatment of anxiety and phobia in children and adolescents: Current status and effects on the emotional response. Clinical Psychology Review, 31, 592-602. doi: 10.1016/j.cpr.2011.01.001

Gallagher, H. M., Rabian, B. A. \& McCloskey, M. S. (2004). A brief group cognitivebehavioral intervention for social phobia in childhood. Journal of Anxiety Disorders, 18, 459-479. doi: 10.1016/s0887-6185(03)00027-6

Ginsburg, G. S. \& Drake, K. L. (2002). School-based treatment for anxious AfricanAmerican adolescents: A controlled pilot study. Journal of the American Academy of Child \& Adolescent Psychiatry, 41, 768-775. doi: 10.1097/00004583-20020700000007 
Ginsburg, G. S., Sakolsky, D., Piacentini, J., Walkup, J. T., Coffey, K. A., Keeton, C. P., ...McCracken, J. T. (2011). Remission after acute treatment in children and adolescents with anxiety disorders: Findings from the CAMS. Journal of Consulting and Clinical Psychology, 79, 806-813. doi: 10.1037/a0025933

Hirshfield-Becker, D. R., Masek, B., Henin, A., Blakely, L. R., Pollock-Wurman, R. A., McQuade, J., .... Rosenbaum, J. F. (2010). Cognitive behavioral therapy for 4-to 7year-old children with anxiety disorders: A randomized clinical trial. Journal of Consulting and Clinical Psychology, 78, 498-510. doi: 10.1037/a0019055

Hudson, J. L., Rapee, R. M., Deveney, C., Schniering, C. A., Lyneham, H. J. \& Bovopoulos, N. (2009). Cognitive-behavioral treatment versus an active control for children and adolescents with anxiety disorders: A randomized trial. Journal of the American Academy of Child \& Adolescent Psychiatry, 48, 533-544. doi:

10.1097/chi.0b013e31819c2401

In-Albon, T. \& Schneider, S. (2007). Psychotherapy of childhood anxiety disorders: A metaanalysis. Psychotherapy and Psychosomatics, 76, 15-24. doi: 10.1159/000096361

Ishikawa, S. I., Okajima, I., Matsuoka, H. \& Sakano, Y. (2007). Cognitive behavioural therapy for anxiety disorders in children and adolescents: A meta-analysis. Child and Adolescent Mental Health, 12, 164-172. doi: 10.1111/j.1475-3588.2006.00433.x

James, A. A., Soler, A. \& Weatherall, R. R. (2005). Cognitive behavioural therapy for anxiety disorders in children and adolescents. The Cochrane Library. doi: 10.1002/14651858.cd004690.pub2

James, A. C., James, G., Cowdrey, F. A., Soler, A. \& Choke, A. (2013). Cognitive behavioural therapy for anxiety disorders in children and adolescents (Review). The Cochrane Library. doi: 10.1002/14651858.cd004690.pub3 
Kendall, P. C., Flannery-Schroeder, E., Panichelli-Mindel, S. M., Southam-Gerow, M., Henin, A. \& Warman, M. (1997). Therapy for youths with anxiety disorders: A second randomized clincal trial. Journal of Consulting and Clinical Psychology, 65, 366-380. doi: 10.1037//0022-006x.65.3.366

Lyneham, H. J. \& Rapee, R. M. (2006). Evaluation of therapist-supported parentimplemented CBT for anxiety disorders in rural children. Behaviour Research and Therapy, 44, 1287-1300. doi: 10.1016/j.brat.2005.09.009

Masia Warner, C., Fisher, P. H., Shrout, P. E., Rathor, S. \& Klein, R. G. (2007). Treating adolescents with social anxiety disorder in school: An attention control trial. Journal of Child Psychology and Psychiatry, 48, 676-686. doi: 10.1111/j.14697610.2007.01737.x

McConachie, H., McLaughlin, E., Grahame, V., Taylor, H., Honey, E., Tavernor, L., Rodgers, J... Steen, N. (2014). Group therapy for anxiety in children with autism spectrum disorder. Autism, 18, 723-732. doi: 10.1177/1362361313488839

Melfsen, S., Kuhnemund, M., Schwieger, J., Warnke, A., Stadler, C., Poustka, F. \& Stangier, U. (2011). Cognitive behavioral therapy of socially phobic children focusing on cognition: a randomised wait-list control study. Child and Adolescent Psychiatry and Mental Health, 5, 1-12. doi: 10.1186/1753-2000-5-5

Moher, D., Liberati, A., Tetzlaff, J. \& Altman, D. G. (2009). Preferred Reporting Items for Systematic Reviews and Meta-Analyses: The PRISMA Statement. PLoS Med, 6. doi: 10.1371/journal.pmed.1000097

Moncrieff, J., Churchill, R., Drummond, D. C. \& McGuire, H. (2001). Development of a quality assessment instrument for trials of treatments for depression and neurosis. International Journal of Methods in Psychiatric Research, 10, 126-133. doi: 10.1002/mpr.108 
Ollendick, T. H., Öst, L.-G., Reuterskiold, L. \& Costa, N. (2010). Comorbidity in youth with specific phobias: Impact of comorbidity on treatment outcome and the impact of treatment on comorbid disorders. Behaviour Research and Therapy, 48, 827-831. doi: 10.1016/j.brat.2010.05.024

Pine, D. S., Cohen, P., Gurley, D., Brook, J. \& Ma, Y. (1998). The risk for early-adulthood anxiety and depressive disorders in adolescents with anxiety and depressive disorders. Archives of General Psychiatry, 55, 56-64. doi: 10.1001/archpsyc.55.1.56

Pina, A. A., \& Silverman, W. K. (2004). Clinical phenomenology, somatic symptoms, and distress in Hispanic/Latino and European American youths with anxiety disorders. Journal of Clinical Child and Adolescent Psychology, 33, 227-236. doi.org/10.1207/s15374424jecp3302_3

Polanczyk, G. V., Salum, G. A., Sugaya, L. S., Caye, A. \& Rohde, L. A. (2015). Annual Research Review: A meta-analysis of the worldwide prevalence of mental disorders in children and adolescents. Journal of Child Psychology and Psychiatry, 56, 345365. doi: $10.1111 /$ jcpp. 12381

Reaven, J., Blakeley-Smith, A., Culhane-Shelburne, K. \& Hepburn, S. (2012). Group cognitive behavior therapy for children with high-functioning autism spectrum disorders and anxiety: A randomized trial. Journal of Child Psychology and Psychiatry, 53, 410-419. doi: 10.1111/j.1469-7610.2011.02486.x

Reynolds, S., Wilson, C., Austin, J. \& Hooper, L. (2012). Effects of psychotherapy for anxiety in children and adolescents: A meta-analytic review. Clinical Psychology Review, 32, 251-262. doi: 10.1016/j.cpr.2012.01.005 
Shortt, A. L., Barrett, P. M. \& Fox, T. L. (2001). Evaluating the FRIENDS program: A cognitive-behavioral group treatment for anxious children and their parents. Journal of Clinical Child Psychology, 30, 525-535. doi: 10.1207/s15374424jccp3004_09

Silk, J. S., Sheeber, L., Tan, P. Z., Ladouceur, C. D., Forbes, E. E., McMakin, D. L., ....Ryan, N. D. (2013). "You can do it!": The role of parental encouragement of bravery in child anxiety treatment. Journal of Anxiety Disorders, 27, 439-446. doi: 10.1016/j.janxdis.2013.06.002

Silk, J. S., Tan, P. Z., Ladouceur, C. D., Mellor, S. M., Siegle, G. J., McMakin, D. L.,...Ryan, N. D. (submitted). A randomized clinical trial comparing individual cognitive behavioral therapy and child-centered therapy for child anxiety disorders.

Silverman, W. K., Kurtines, W. M., Ginsburg, G. S., Weems, C. F., Lumpkin, P. W. \& Carmichael, D. H. (1999). Treating anxiety disorders in children with group cognitive-behavioral therapy: A randomized clinical trial. Journal of Consulting and Clinical Psychology, 67, 995-1003. doi: 10.1037/0022-006x.67.6.995

Silverman, W. K., Pina, A. A. \& Viswesvaran, C. (2008). Evidence-based psychosocial treatments for phobic and anxiety disorders in children and adolescents. Journal of Clinical Child \& Adolescent Psychology, 37, 105-130. doi:

$10.1080 / 15374410701817907$

Spence, S. H., Donovan, C. L. \& Brechman-Toussaint, M. (2000). The treatment of childhood social phobia: The effectiveness of a social skills training-based, cognitivebehavioural intervention, with and without parental involvement. Journal of Child Psychology and Psychiatry, 41, 713-726. doi: 10.1017/s0021963099005934

Spence, S. H., Holmes, J. M., March, S. \& Lipp, O. V. (2006). The feasibility and outcome of clinic plus internet delivery of cognitive-behavior therapy for childhood anxiety. 
Journal of Consulting and Clinical Psychology, 74, 614-621. doi: 10.1037/0022006x.74.3.614

Storch, E. A., Arnold, E. B., Lewin, A. B., Nadeau, J. M., Jones, A. M., De Nadai, A. S., ... Murphy, T. K. (2013). The effect of cognitive-behavioral therapy versus treatment as usual for anxiety in children with autism spectrum disorders: a randomized, controlled trial. Journal of the American Academy of Child \& Adolescent Psychiatry, 52, $132-$ 142. e132. Doi: 10.1016/j.jaac.2012.11.007

Storch, E. A., Lewin, A. B., Collier, A. B., Arnold, E., De Nadai, A. S., Dane, B. F., ....Murphy, T. K. (2015). A randomised controlled trial of cognitive-behavioral therapy versus treatment as usual for adolescents with autism spectrum disorders and comorbid anxiety Depression and Anxiety, 32, 174-181.

Thirlwall, K., Cooper, P. J., Karalus, J., Voysey, M., Willetts, L. \& Creswell, C. (2013). Treatment of child anxiety disorders via guided parent-delivered cognitivebehavioural therapy: randomised controlled trial. British Journal of Psychiatry, 203, 436-444. doi: 10.1002/da.22332

Waite, P. \& Creswell, C. (2014). Children and adolescents referred for treatment of anxiety disorders: Differences in clinical characteristics. Journal of Affective Disorders, 167, 326-332. doi: 10.1016/j.jad.2014.06.028

Waters, A. M., Ford, L. A., Wharton, T. A. \& Cobham, V. E. (2009). Cognitive-behavioural therapy for young children with anxiety disorders: Comparison of a child + parent condition versus a parent only condition. Behaviour Research and Therapy, 47, 654662.

Wood, J. J., Drahota, A., Sze, K., Har, K., Chiu, A. \& Langer, D. A. (2009). Cognitive behavioral therapy for anxiety in children with autism spectrum disorders: A 
randomized, controlled trial. Journal of Child Psychology and Psychiatry, 50, 224234. doi: 10.1016/j.brat.2009.04.008

Woodward, L. J. \& Fergusson, D. M. (2001). Life course outcomes of young people with anxiety disorders in adolescence. Journal of the American Academy of Child and Adolescent Psychiatry, 40, 1086-1093. doi: 10.1097/00004583-200109000-00018 
Figure 1

\section{Prisma flowchart}

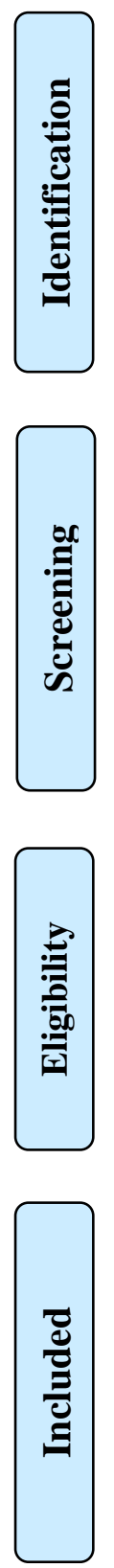

Studies from James et al. (2013) systematic review

$$
\mathrm{k}=42
$$

(41 studies included in James et al.,

+1 excluded study involving a brief intervention)

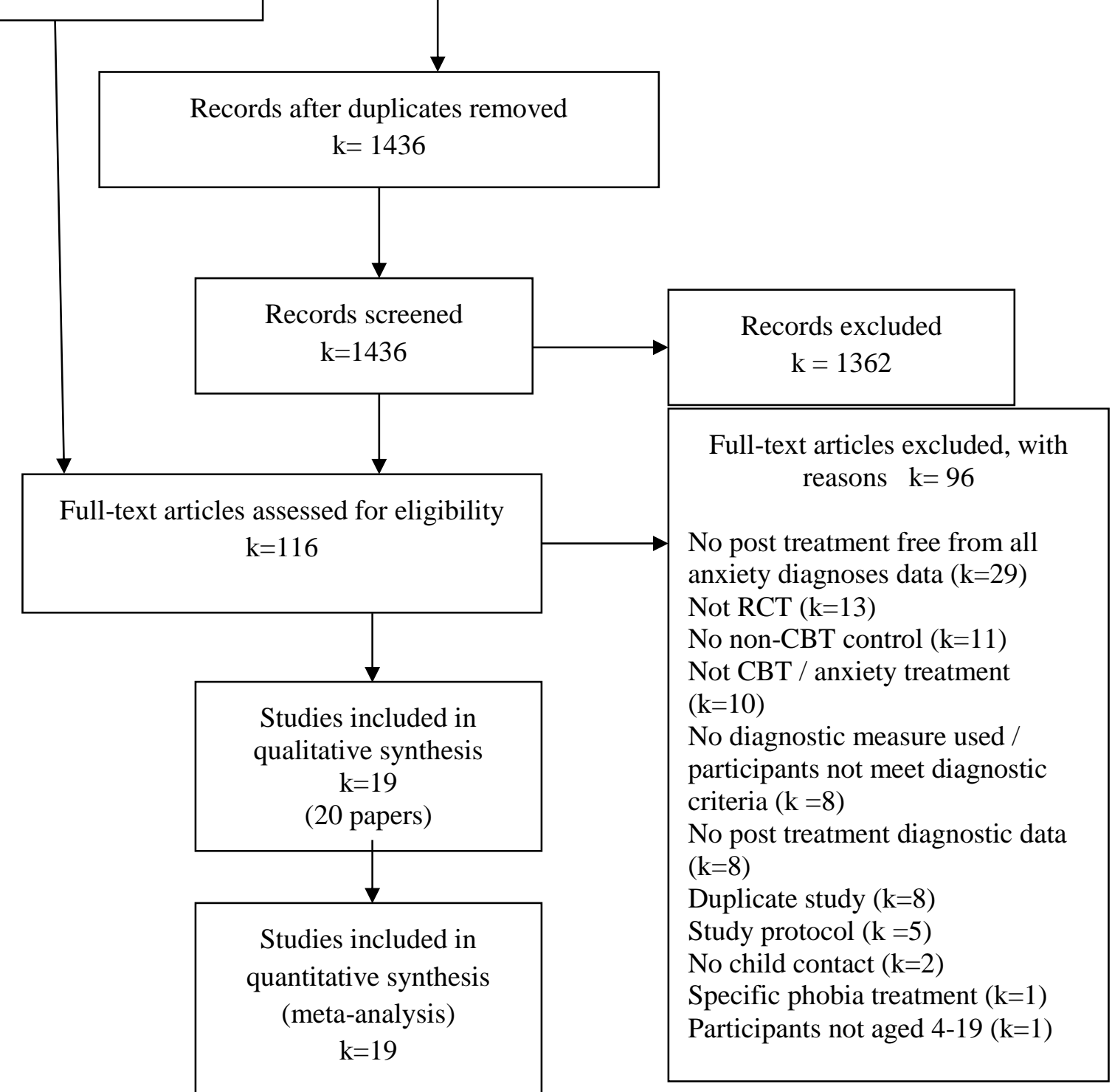


Figure 2

Forest plot: CBT vs wait list (non-ASC samples)

\begin{tabular}{|c|c|c|}
\hline Barrett et al. 1996 (child) & $\longmapsto$ & $1.49[0.31,2.67]$ \\
\hline Barrett 1996 et al. (family) & $\longmapsto$ & $2.86[1.46,4.27]$ \\
\hline Barrett 1998 (child) & $\square$ & $1.36[0.06,2.67]$ \\
\hline Barrett 1998 (family) & $\longmapsto$ & $1.97[0.52,3.43$ ] \\
\hline Chiu et al. 2013 & $\longrightarrow$ & $4.65[2.30,7.01]$ \\
\hline Cobham 2012 & & $4.43[1.45,7.41]$ \\
\hline Dadds et al. 1997 & $\mapsto$ & $0.37[-0.45,1.20]$ \\
\hline Hirshfeld-Becker et al.2010 & 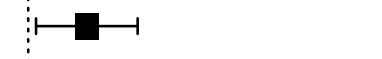 & $1.20[0.17,2.24]$ \\
\hline Shortt et al. 2001 & $\longmapsto$ & $3.22[1.13,5.32]$ \\
\hline Spence et al. 2006 & $\longrightarrow$ & $2.35[0.68,4.03]$ \\
\hline Waters et al. 2009 & $\rightarrow$ & $1.31[-0.38,3.00]$ \\
\hline RE Model & & $1.95[1.25,2.64]$ \\
\hline$\Gamma$ & $T$ & \\
\hline-2.00 & 2.00 & \\
\hline & Log Odds Ratio & \\
\hline
\end{tabular}


Figure 3

Forest plot: CBT vs active control (non-ASC samples)

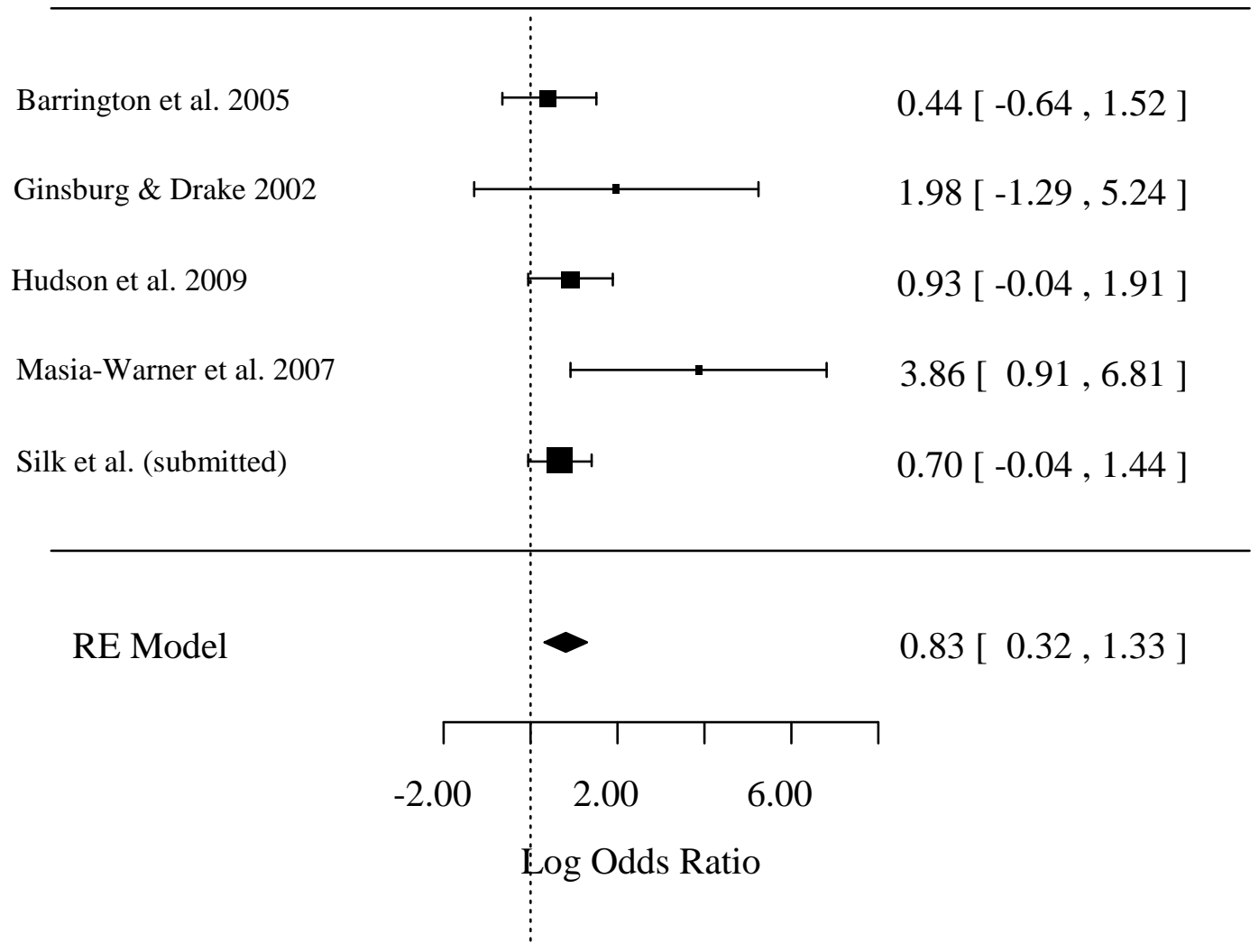


Figure 4

Forest plot: CBT vs wait-list control (ASC samples)

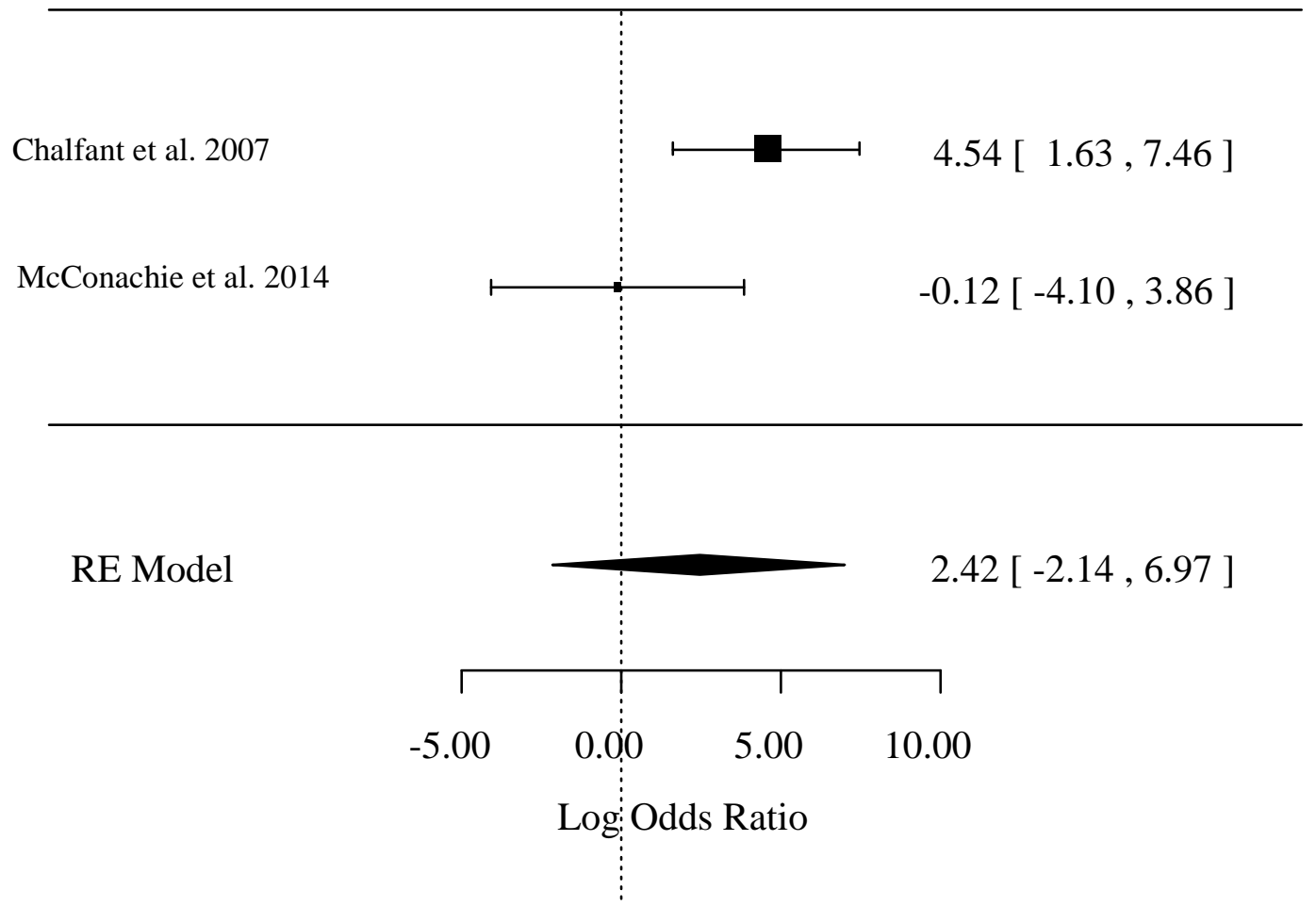


Figure 5

Forest plot: CBT vs active control (ASC samples)

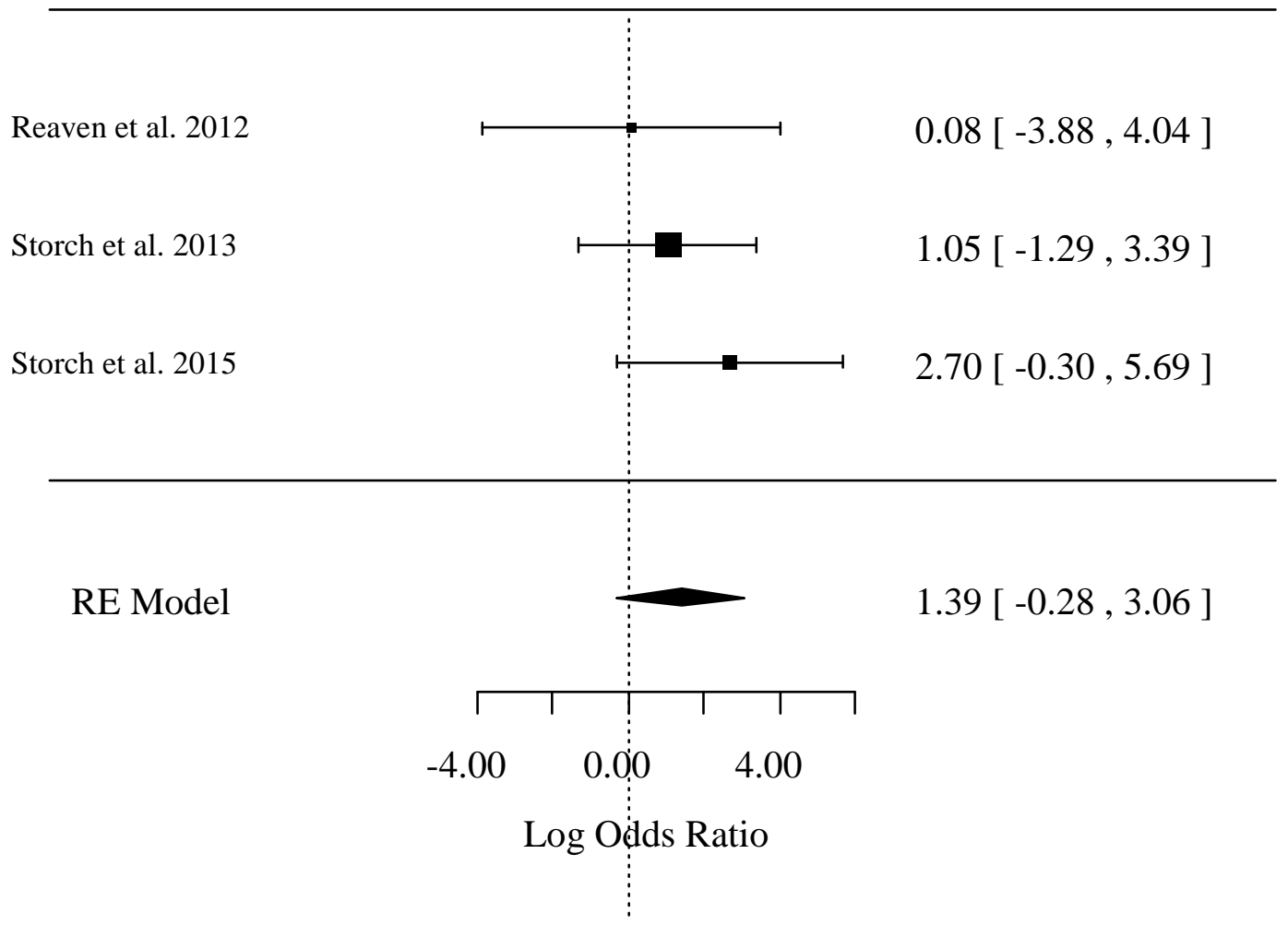


Table 1

Study characteristics of included studies

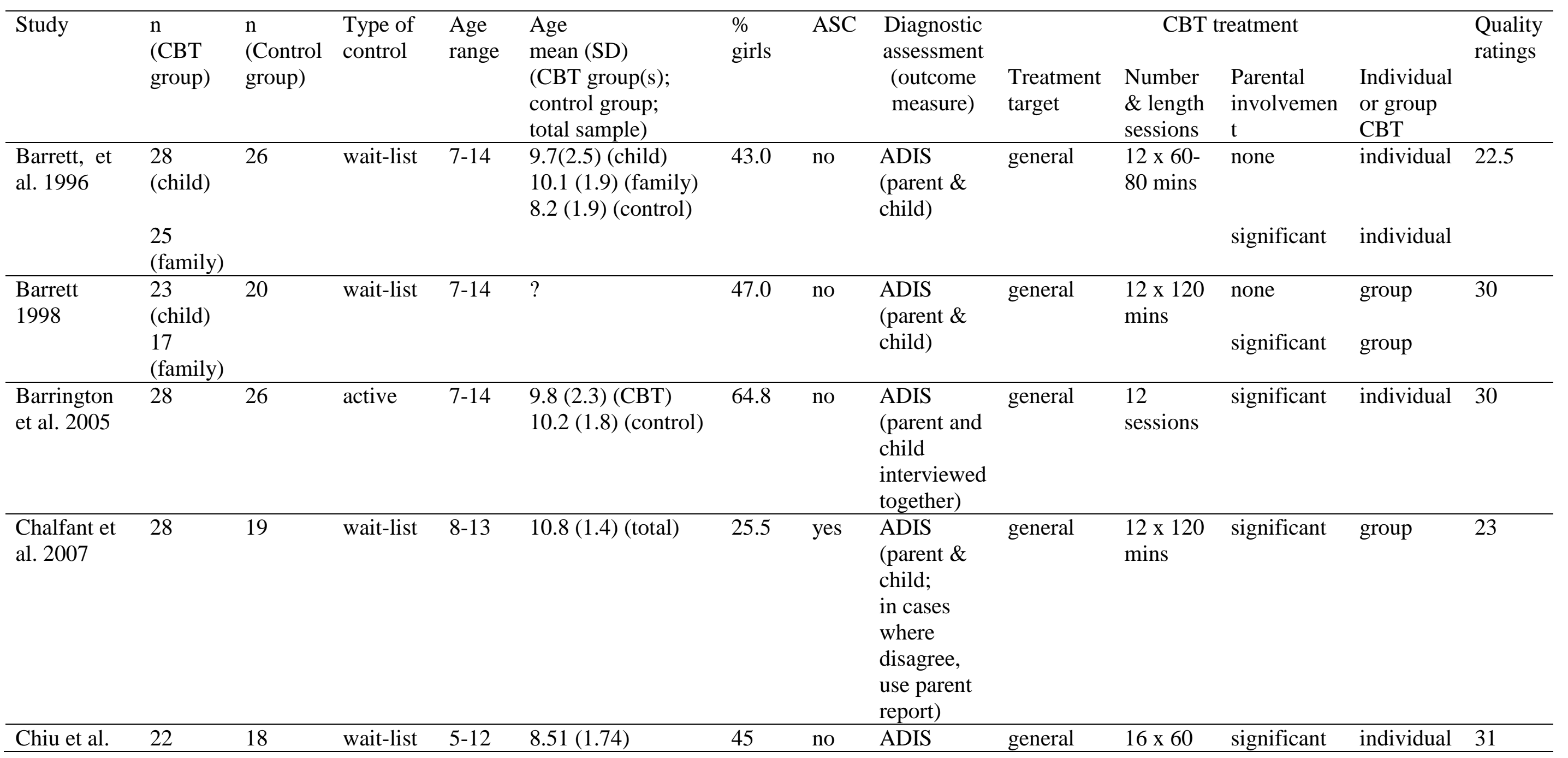




\begin{tabular}{|c|c|c|c|c|c|c|c|c|c|c|c|c|c|}
\hline 2013 & & & & & & & & $\begin{array}{l}\text { (parent \& } \\
\text { child) }\end{array}$ & & $\operatorname{mins}$ & & & \\
\hline $\begin{array}{l}\text { Cobham } \\
2012\end{array}$ & 23 & 12 & wait-list & $7-14$ & $\begin{array}{l}9.7(2.5)(\mathrm{CBT}) \\
9.8(2.7) \text { (control) }\end{array}$ & 45.7 & no & $\begin{array}{l}\text { ADIS } \\
\text { (parent \& } \\
\text { child - pre; } \\
\text { parent } \\
\text { telephone } \\
\text { interview - } \\
\text { post) }\end{array}$ & general & $\begin{array}{l}6 \times 60 \\
\text { mins } \\
\text { (child) } \\
6 \times 90 \\
\text { mins } \\
\text { (parent) }\end{array}$ & significant & individual & 30 \\
\hline $\begin{array}{l}\text { Dadds et al. } \\
1997^{\text {a d }}\end{array}$ & 42 & 53 & wait-list & $7-14$ & $\begin{array}{l}9.4(1.5)(\mathrm{CBT}) \\
9.2(1.7) \text { (control) } \\
9.3(1.6)(\text { total })\end{array}$ & 73.7 & no & $\begin{array}{l}\text { ADIS } \\
\text { (parent } \\
\text { only) }\end{array}$ & general & $\begin{array}{l}10 \times 60- \\
120 \text { mins }\end{array}$ & Some & group & $29 / 30$ \\
\hline $\begin{array}{l}\text { Ginsburg \& } \\
\text { Drake 2002 } \\
\end{array}$ & 6 & 6 & active & $14-17$ & 15.6 (total) & 83.0 & no & $\begin{array}{l}\text { ADIS } \\
\text { (child only) }\end{array}$ & general & $\begin{array}{l}10 \times 45 \\
\text { mins }\end{array}$ & None & group & 23 \\
\hline $\begin{array}{l}\text { Hirshfeld- } \\
\text { Becker et } \\
\text { al. } 2010\end{array}$ & 34 & 30 & wait-list & $4-7$ & 5.4 (1) (total) & 53.0 & no & K-SADS & general & $\begin{array}{l}15-20 \\
\text { sessions }\end{array}$ & significant & individual & 36 \\
\hline $\begin{array}{l}\text { Hudson et } \\
\text { al. } 2009\end{array}$ & 60 & 52 & active & $7-16$ & $\begin{array}{l}10.2(2.4)(\mathrm{CBT}) \\
10.2(2.7) \text { (control) } \\
10.2 \text { (total) }\end{array}$ & & no & $\begin{array}{l}\text { ADIS } \\
\text { (parent \& } \\
\text { child) } \\
\end{array}$ & general & $\begin{array}{l}10 \times 120 \\
\text { mins }\end{array}$ & significant & group & 31.5 \\
\hline $\begin{array}{l}\text { Masia- } \\
\text { Warner et } \\
\text { al. } 2007 \\
\end{array}$ & 19 & 17 & active & $14-16$ & $15.1(0.6)$ & 83.3 & no & $\begin{array}{l}\text { ADIS } \\
\text { (parent \& } \\
\text { child) } \\
\end{array}$ & $\begin{array}{l}\text { social } \\
\text { anxiety }\end{array}$ & $\begin{array}{l}14 \times 40 \\
\text { mins }\end{array}$ & minimal & group & 34 \\
\hline $\begin{array}{l}\text { McConachi } \\
\text { e et al. } 2014\end{array}$ & 17 & 15 & wait-list & $9-13$ & $\begin{array}{l}11.7(1.4)(\mathrm{CBT}) \\
11.8(1.3) \text { (control) }\end{array}$ & 12.5 & yes & $\begin{array}{l}\text { ADIS } \\
\text { (parent } \\
\text { only) } \\
\end{array}$ & general & $\begin{array}{l}7 \times 120 \\
\text { mins }\end{array}$ & significant & group & 34 \\
\hline $\begin{array}{l}\text { Reaven et } \\
\text { al. } 2012^{\mathrm{d}}\end{array}$ & 24 & 26 & active & $7-14$ & $\begin{array}{l}10.5(1.8)(\mathrm{CBT}) \\
10.4(1.7) \text { (control) } \\
10.5(1.7) \text { (total) }\end{array}$ & 4.0 & yes & $\begin{array}{l}\text { ADIS } \\
\text { (parent } \\
\text { only) }\end{array}$ & general & $\begin{array}{l}12 \times 90 \\
\text { mins }\end{array}$ & significant & group & 34 \\
\hline $\begin{array}{l}\text { Shortt et } \\
\text { al.2001 }\end{array}$ & 54 & 17 & wait-list & $6.5-10$ & $\begin{array}{l}7.8 \text { (1.3) (CBT) } \\
7.9(1.3) \text { (control) }\end{array}$ & 59.0 & no & DISCAP & general & $\begin{array}{l}12 \times 50- \\
60 \text { mins }\end{array}$ & significant & group & 31 \\
\hline
\end{tabular}




\begin{tabular}{|c|c|c|c|c|c|c|c|c|c|c|c|c|}
\hline & & & & & 7.9 & & & & & $\begin{array}{l}\text { (child) } \\
10 \times 30- \\
40 \text { mins } \\
\text { (parents) }\end{array}$ & & \\
\hline $\begin{array}{l}\text { Silk et al. } \\
\text { submitted }^{\text {de }}\end{array}$ & 92 & 43 & active & $9-14$ & $\begin{array}{l}10.9 \text { (1.4) (CBT) } \\
11.0(1.6) \text { (control) }\end{array}$ & 55.7 & no & K-SADS & general & $\begin{array}{ll}14 & \text { minimal } \\
\text { sessions } & \\
\text { (child) } & \\
2 \text { parents } & \end{array}$ & individual & 29 \\
\hline $\begin{array}{l}\text { Spence et } \\
\text { al. } 2006^{\mathrm{b}}\end{array}$ & 22 & 23 & wait-list & $7-14$ & $\begin{array}{l}10.3(2.1)(\mathrm{CBT}) \\
9.7(1.7) \text { (control) }\end{array}$ & 42.2 & no & $\begin{array}{l}\text { ADIS } \\
\text { (parent) }\end{array}$ & general & $\begin{array}{l}10 \times 60 \\
\text { mins } \\
\text { (child) } \\
6 \times 60 \\
\text { mins } \\
\text { (parent) }\end{array}$ & group & 32 \\
\hline $\begin{array}{l}\text { Storch et al. } \\
2013\end{array}$ & 24 & 21 & active & $7-11$ & $\begin{array}{l}8.8(1.3) \text { (CBT) } \\
9.0(1.4) \text { (control) } \\
8.9(1.3) \text { (total) }\end{array}$ & 20.0 & yes & $\begin{array}{l}\text { ADIS } \\
\text { (parent \& } \\
\text { child) }\end{array}$ & general & $\begin{array}{l}16 \times 60-\text { significant } \\
90 \text { mins }\end{array}$ & individual & 36 \\
\hline $\begin{array}{l}\text { Storch et al. } \\
2015\end{array}$ & 16 & 15 & active & $11-16$ & $\begin{array}{l}12.8(1.2)(\mathrm{CBT}) \\
12.7(1.5) \text { (control) } \\
12.7(1.3) \text { (total) } \\
\end{array}$ & 19.4 & yes & $\begin{array}{l}\text { ADIS } \\
\text { (parent \& } \\
\text { child) } \\
\end{array}$ & general & $\begin{array}{l}16 \times 60- \\
90 \text { mins }\end{array}$ & individual & 32 \\
\hline $\begin{array}{l}\text { Waters et } \\
\text { al. } 2009^{c}\end{array}$ & 31 & 11 & wait-list & $4-8$ & $\begin{array}{l}6.9(1.3)(\mathrm{CBT}) \\
6.8(1.0) \text { (control) }\end{array}$ & & no & $\begin{array}{l}\text { ADIS } \\
\text { (parent } \\
\text { only) } \\
\end{array}$ & general & $\begin{array}{l}10 \times 60 \\
\text { mins }\end{array}$ & group & 31 \\
\hline
\end{tabular}

$a=$ Dadds et al.1999 provides follow-up data for study

$b=$ clinic+internet group not included

$c=$ parent only condition not included

$d=$ data provided by author

$e=$ manuscript provided by author (same study as Silk et al. 2013) 
Table 2

Number of participants free from all anxiety diagnoses and primary diagnoses, post-treatment and at follow-up

\begin{tabular}{|c|c|c|c|c|c|c|c|c|}
\hline \multirow[t]{2}{*}{ Study } & \multicolumn{2}{|c|}{$\begin{array}{l}\text { Post treatment outcome } \\
\text { CBT group }\end{array}$} & \multicolumn{2}{|c|}{$\begin{array}{l}\text { Post treatment outcome } \\
\text { control group }\end{array}$} & \multicolumn{2}{|c|}{$\begin{array}{l}\text { Follow-up outcome } \\
\text { CBT group }\end{array}$} & \multicolumn{2}{|c|}{$\frac{\text { Follow up outcome }}{\text { control group }}$} \\
\hline & $\begin{array}{l}\text { Number free } \\
\text { from all } \\
\text { anxiety } \\
\text { diagnoses (\%) }\end{array}$ & $\begin{array}{l}\text { Number free } \\
\text { from primary } \\
\text { diagnosis }(\%)\end{array}$ & $\begin{array}{l}\text { Number free } \\
\text { from all } \\
\text { anxiety } \\
\text { diagnoses (\%) }\end{array}$ & $\begin{array}{l}\text { Number free } \\
\text { from primary } \\
\text { diagnosis }(\%)\end{array}$ & $\begin{array}{l}\text { Number free } \\
\text { from all } \\
\text { anxiety } \\
\text { diagnoses } \\
(\%)\end{array}$ & $\begin{array}{l}\text { Number free } \\
\text { from primary } \\
\text { diagnosis } \\
(\%)\end{array}$ & $\begin{array}{l}\text { Number } \\
\text { free from } \\
\text { all anxiety } \\
\text { diagnoses } \\
(\%)\end{array}$ & $\begin{array}{l}\text { Number free } \\
\text { from primary } \\
\text { diagnosis }(\%)\end{array}$ \\
\hline $\begin{array}{l}\text { Barrett et } \\
\text { al.1996 (child } \\
\text { only) }\end{array}$ & $16(57.1)$ & & $6(23.1)$ & & & & & \\
\hline $\begin{array}{l}\text { Barrett et } \\
\text { al.1996 (family) }\end{array}$ & $21(84)$ & & $6(23.1)$ & & & & & \\
\hline $\begin{array}{l}\text { Barrett } 1998 \\
\text { (child only) }\end{array}$ & $13(56.5)$ & & $5(25.0)$ & & & & & \\
\hline $\begin{array}{l}\text { Barrett } 1998 \\
\text { (family) }\end{array}$ & $12(70.6)$ & & $5(25.0)$ & & & & & \\
\hline $\begin{array}{l}\text { Barrington et } \\
\text { al.2005 }\end{array}$ & $17(60.7)$ & & $13(50.0)$ & & $\begin{array}{l}6 \text { months: } \\
22 \text { (78.6) }\end{array}$ & & $\begin{array}{l}6 \text { months: } \\
18 \text { (69.2) }\end{array}$ & \\
\hline & & & & & $\begin{array}{l}12 \text { months: } \\
21 \text { (75.0) }\end{array}$ & & $\begin{array}{l}12 \text { months: } \\
18 \text { (69.2) }\end{array}$ & \\
\hline $\begin{array}{l}\text { Chalfant et } \\
\text { al. } 2007^{\mathrm{a}}\end{array}$ & $20(71.4)$ & & $0(0.0)$ & & & & & \\
\hline Chiu et al. 2013 & $21(95.5)$ & & $3(16.7)$ & & & & & \\
\hline Cobham 2012 & $18(78.3)$ & & $0(0.0)$ & & & & & \\
\hline
\end{tabular}




\begin{tabular}{|c|c|c|c|c|c|c|c|c|}
\hline $\begin{array}{l}\text { Dadds et } \\
\text { al.1997/Dadds }\end{array}$ & $26(61.9)$ & & $28(52.8)$ & & $\begin{array}{l}6 \text { months: } \\
28(66.7)\end{array}$ & & $\begin{array}{l}6 \text { months: } \\
22(41.5)\end{array}$ & \\
\hline & & & & & $21(50.0)$ & $21(50.0)$ & $27(50.9)$ & $27(50.9)$ \\
\hline & & & & & $28(66.7)$ & $28(66.7)$ & $26(49.1)$ & $26(49.1)$ \\
\hline $\begin{array}{l}\text { Ginsburg \& } \\
\text { Drake } 2002\end{array}$ & $2(33.3)$ & $3(50.0)$ & $0(0.0)$ & $1(16.7)$ & & & & \\
\hline $\begin{array}{l}\text { Hirshfeld- } \\
\text { Becker et } \\
\text { al.2010 }\end{array}$ & $20(58.8)$ & & $9(30.0)$ & & & & & \\
\hline $\begin{array}{l}\text { Hudson et } \\
\text { al.2009 }\end{array}$ & $17(28.3)$ & $23(38.3)$ & 7 (13.5) & $13(25.0)$ & $\begin{array}{l}3 \text { months: } \\
25 \text { (41.7) }\end{array}$ & $\begin{array}{l}3 \text { months: } \\
35 \text { (58.3) }\end{array}$ & $\begin{array}{l}3 \text { months: } \\
13 \text { (25.0) }\end{array}$ & $\begin{array}{l}3 \text { months: } \\
20 \text { (38.5) }\end{array}$ \\
\hline $\begin{array}{l}\text { Masia-Warner } \\
\text { et al. } 2007^{\mathrm{a}}\end{array}$ & $11(57.9)$ & $11(57.9)$ & $0(0.0)$ & $0(0.0)$ & $\begin{array}{l}6 \text { months: } \\
10 \text { (52.6) }\end{array}$ & $\begin{array}{l}6 \text { months: } \\
11 \text { (57.9) }\end{array}$ & $\begin{array}{l}6 \text { months: } \\
1(5.9)\end{array}$ & $\begin{array}{l}6 \text { months: } \\
1(5.9)\end{array}$ \\
\hline $\begin{array}{l}\text { McConachie et } \\
\text { al.2014 }\end{array}$ & $0(0.0)$ & $0(0.0)$ & $0(0.0)$ & $0(0.0)$ & & & & \\
\hline $\begin{array}{l}\text { Silk et al. } \\
\text { submitted }^{\text {a }}\end{array}$ & $50(54.3)$ & & $16(37.2)$ & & $\begin{array}{l}12 \text { months: } \\
52 \text { (56.5) }\end{array}$ & & $\begin{array}{l}12 \text { months: } \\
12 \text { (27.9) }\end{array}$ & \\
\hline $\begin{array}{l}\text { Spence et al. } \\
2006\end{array}$ & $11(50.0)$ & $13(59.1)$ & $2(8.7)$ & $3(13.0)$ & & & & \\
\hline $\begin{array}{l}\text { Storch et } \\
\text { al. } 2013^{\mathrm{a}}\end{array}$ & $3(12.5)$ & $9(37.5)$ & $1(4.8)$ & $1(4.8)$ & & & & \\
\hline $\begin{array}{l}\text { Storch et } \\
\text { al. } 2015^{\mathrm{a}}\end{array}$ & $5(31.3)$ & $6(37.5)$ & $0(0.0)$ & $0(0.0)$ & & & & \\
\hline $\begin{array}{l}\text { Waters et } \\
\text { al.2009 }\end{array}$ & $14(45.2)$ & $17(54.8)$ & $2(18.2)$ & $2(18.2)$ & & & & \\
\hline
\end{tabular}


Appendices

Appendix A

Search Strategy

Search strategy used by James et al (2013) replicated, as detailed below:

OVID MEDLINE search strategy

1. COGNITIVE THERAPY/

2. BEHAVIOR THERAPY/

3. (cogniti adj3 (behavio $\$$ or intervention $\$$ or psychotherap\$ or technique $\$$ or therap $\$$ or treat\$)).ti,ab.

4. (behavio $\$$ adj3 (intervention $\$$ or psychotherapy $\$$ or technique $\$$ or therap $\$$ or treat $\$$ )).ti,ab.

5. or/1-4

6. exp ANXIETY DISORDERS/

7. (anxiety or anxious or panic or phobi\$).ti,ab.

8. or/6-7

9. (child $\$$ or adolesc $\$$ or juvenile $\$$ or minors or $\mathrm{p}$ ? ediatri $\$$ or teen* or school\$ or young or youth\$).mp.

10. randomized controlled trial.pt.

11. controlled clinical trial.pt.

12. randomi\#ed.ab.

13. placebo\$.ab.

14. randomly.ab.

15. trial.ab.

16. groups.ab.

17. (clinic\$ adj3 (trial\$ or study or studies\$)).ti,ab.

18. (control\$ or prospectiv\$ or volunteer $\$$ ).ti,ab.

19. or/10-18

20. 5 and 8 and 9 and 19

(Our search was limited to 2012 onwards) 
Appendix B

Excluded studies

\begin{tabular}{|c|c|}
\hline Study & $\begin{array}{l}\text { Reason for } \\
\text { exclusion }\end{array}$ \\
\hline $\begin{array}{l}\text { Afshari, A., Neshat-Doost, H. T., Maracy, M. R., Ahmady, M. K., \& } \\
\text { Amiri, S. (2014). The effective comparison between emotion-focused } \\
\text { cognitive behavioral group therapy and cognitive behavioral group } \\
\text { therapy in children with separation anxiety disorder. Journal of Research } \\
\text { in Medical Sciences: The official journal of Isfahan University of Medical } \\
\text { Sciences, } 19(3), 221 .\end{array}$ & $\begin{array}{l}\text { No post } \\
\text { treatment } \\
\text { diagnostic data }\end{array}$ \\
\hline $\begin{array}{l}\text { Batra, P. (2013). Evaluation of the Hong Kong FRIENDS Intervention } \\
\text { Program for Childhood Anxiety. Alliant International University. }\end{array}$ & Not RCT \\
\hline $\begin{array}{l}\text { Beidas, R. S., Lindhiem, O., Brodman, D. M., Swan, A., Carper, M., } \\
\text { Cummings, C., .. Piacentini, J. (2014). A probabilistic and individualized } \\
\text { approach for predicting treatment gains: An extension and application to } \\
\text { anxiety disordered youth. Behavior Therapy, 45(1), 126-136. } \\
\text { doi:10.1016/j.beth.2013.05.001 }\end{array}$ & Duplicate study \\
\hline $\begin{array}{l}\text { Benjamin, C. L., Harrison, J. P., Settipani, C. A., Brodman, D. M., \& } \\
\text { Kendall, P. C. (2013). Anxiety and related outcomes in young adults } 7 \text { to } \\
19 \text { years after receiving treatment for child anxiety. Journal of Consulting } \\
\text { and Clinical Psychology, } 81(5), 865 \text {. }\end{array}$ & $\begin{array}{l}\text { No non-CBT } \\
\text { control (Follow } \\
\text { up study) }\end{array}$ \\
\hline $\begin{array}{l}\text { Bouchard, S., Gervais, J., Gagnier, N., \& Loranger, C. (2013). Evaluation } \\
\text { of a primary prevention program for anxiety disorders using story books } \\
\text { with children aged 9-12 years. The Journal of Primary Prevention, 34(5), } \\
\text { 345-358. doi.org/10.1037/a0033048 }\end{array}$ & $\begin{array}{l}\text { No diagnostic } \\
\text { measures used }\end{array}$ \\
\hline $\begin{array}{l}\text { Britton, J. C., Bar-Haim, Y., Clementi, M. A., Sankin, L. S., Chen, G., } \\
\text { Shechner, T., .. Pine, D. S. (2013). Training-associated changes and } \\
\text { stability of attention bias in youth: implications for attention bias } \\
\text { modification treatment for pediatric anxiety. Developmental Cognitive } \\
\text { Neuroscience, 4, 52-64. doi: 10.1016/j.dcn.2012.11.001 }\end{array}$ & $\begin{array}{l}\text { Not CBT } \\
\text { only/based } \\
\text { treatment trial }\end{array}$ \\
\hline $\begin{array}{l}\text { Caporino, N. E., Brodman, D. M., Kendall, P. C., Albano, A. M., Sherrill, } \\
\text { J., Piacentini, J....Ginsburg, G. (2013). Defining treatment response and } \\
\text { remission in child anxiety: signal detection analysis using the pediatric } \\
\text { anxiety rating scale. Journal of the American Academy of Child \& } \\
\text { Adolescent Psychiatry, 52(1), 57-67. doi: } 10.1016 / \text { j.jaac.2012.10.006 }\end{array}$ & Duplicate study \\
\hline $\begin{array}{l}\text { Chavira, D. A., Drahota, A., Garland, A. F., Roesch, S., Garcia, M., \& } \\
\text { Stein, M. B. (2014). Feasibility of two modes of treatment delivery for } \\
\text { child anxiety in primary care. Behaviour Research and Therapy, 60, 60- } \\
\text { 66. doi: } 10.1016 / \text { j.brat.2014.06.010 }\end{array}$ & $\begin{array}{l}\text { No non-CBT } \\
\text { control }\end{array}$ \\
\hline
\end{tabular}




\begin{tabular}{|c|c|}
\hline $\begin{array}{l}\text { Chorpita, B. F., Weisz, J. R., Daleiden, E. L., Schoenwald, S. K., } \\
\text { Palinkas, L. A., Miranda, J., ...Borntrager, C. F. (2013). Long-term } \\
\text { outcomes for the Child STEPs randomized effectiveness trial: A } \\
\text { comparison of modular and standard treatment designs with usual care. } \\
\text { Journal of Consulting and Clinical Psychology, 81(6), 999. doi: } \\
\text { 10.1037/a0034200 }\end{array}$ & $\begin{array}{l}\text { No diagnostic } \\
\text { measures used }\end{array}$ \\
\hline $\begin{array}{l}\text { Compton, S. N., Peris, T. S., Almirall, D., Birmaher, B., Sherrill, J., } \\
\text { Kendall, P. C., ... Rynn, M. A. (2014). Predictors and moderators of } \\
\text { treatment response in childhood anxiety disorders: Results from the } \\
\text { CAMS trial. Journal of Consulting and Clinical Psychology, 82(2), } 212 . \\
\text { doi: } 10.1037 / \text { a0035458 }\end{array}$ & Duplicate study \\
\hline $\begin{array}{l}\text { Crawford, E. A., Salloum, A., Lewin, A. B., Andel, R., Murphy, T. K., \& } \\
\text { Storch, E. A. (2013). A pilot study of computer-assisted cognitive } \\
\text { behavioral therapy for childhood anxiety in community mental health } \\
\text { centers. Journal of Cognitive Psychotherapy, 27(3), 221-234. doi: } \\
\text { 10.1891/0889-8391.27.3.221 }\end{array}$ & Not RCT \\
\hline $\begin{array}{l}\text { Crawley, S. A., Caporino, N. E., Birmaher, B., Ginsburg, G., Piacentini, } \\
\text { J., Albano, A. M., .. Rynn, M. (2014). Somatic complaints in anxious } \\
\text { youth. Child Psychiatry \& Human Development, 45(4), 398-407. doi: } \\
\text { 10.1007/s10578-013-0410-x }\end{array}$ & Duplicate study \\
\hline $\begin{array}{l}\text { Cummings, C. M., Caporino, N. E., Settipani, C. A., Read, K. L., } \\
\text { Compton, S. N., March, J., ...Walkup, J. T. (2013). The therapeutic } \\
\text { relationship in cognitive-behavioral therapy and pharmacotherapy for } \\
\text { anxious youth. Journal of Consulting and Clinical Psychology, 81(5), } \\
\text { 859. doi: 10.1037/a0033294 }\end{array}$ & $\begin{array}{l}\text { No diagnostic } \\
\text { measures used }\end{array}$ \\
\hline $\begin{array}{l}\text { Dahan, J. (2013). Individual Child Cognitive Behavioral Treatment versus } \\
\text { Child-Parent Cognitive Behavioral Treatments for Anxiety Disorders in } \\
\text { Children and Adolescents: Comparative Outcomes. }\end{array}$ & $\begin{array}{l}\text { No non-CBT } \\
\text { control }\end{array}$ \\
\hline $\begin{array}{l}\text { de Souza, M. A. M., Salum, G. A., Jarros, R. B., Isolan, L., Davis, R., } \\
\text { Knijnik, D., .. Heldt, E. (2013). Cognitive-behavioral group therapy for } \\
\text { youths with anxiety disorders in the community: effectiveness in low and } \\
\text { middle income countries. Behavioural and Cognitive Psychotherapy, } \\
\text { 41(03), 255-264. doi: 10.1017/s1352465813000015 }\end{array}$ & Not RCT \\
\hline $\begin{array}{l}\text { Essau, C. A., Conradt, J., Sasagawa, S., \& Ollendick, T. H. (2012). } \\
\text { Prevention of anxiety symptoms in children: Results from a universal } \\
\text { school-based trial. Behavior Therapy, 43(2), 450-464. doi: } \\
\text { 10.1348/014466501163887 }\end{array}$ & $\begin{array}{l}\text { No diagnostic } \\
\text { measures used }\end{array}$ \\
\hline $\begin{array}{l}\text { Festen, H., Hartman, C. A., Hogendoorn, S., de Haan, E., Prins, P. J., } \\
\text { Reichart, C. G., .. Nauta, M. H. (2013). Temperament and parenting } \\
\text { predicting anxiety change in cognitive behavioral therapy: The role of } \\
\text { mothers, fathers, and children. Journal of Anxiety Disorders, 27(3), 289- }\end{array}$ & $\begin{array}{l}\text { No non-CBT } \\
\text { control data }\end{array}$ \\
\hline
\end{tabular}




\begin{tabular}{|c|c|}
\hline 97. doi: 10.1016/j.janxdis.2013.03.001 & \\
\hline $\begin{array}{l}\text { Flannery-Schroeder, E. C., \& Kendall, P. C. (2000). Group and individual } \\
\text { cognitive-behavioral treatments for youth with anxiety disorders: A } \\
\text { randomized clinical trial. Cognitive Therapy and Research, 24(3), 251- } \\
\text { 278. doi: } 10.1007 / \mathrm{s} 10608-005-3168-\mathrm{z}\end{array}$ & $\begin{array}{l}\text { No post } \\
\text { treatment free } \\
\text { from all anxiety } \\
\text { diagnoses data }\end{array}$ \\
\hline $\begin{array}{l}\text { Fox, J. K., Warner, C. M., Lerner, A. B., Ludwig, K., Ryan, J. L., } \\
\text { Colognori, D., .. Brotman, L. M. (2012). Preventive intervention for } \\
\text { anxious preschoolers and their parents: strengthening early emotional } \\
\text { development. Child Psychiatry \& Human Development, 43(4), 544-559. } \\
\text { doi: 10.1007/s10578-012-0283-4 }\end{array}$ & $\begin{array}{l}\text { No diagnostic } \\
\text { measures used }\end{array}$ \\
\hline $\begin{array}{l}\text { Fujii, C., Renno, P., McLeod, B. D., Lin, C. E., Decker, K., Zielinski, K., } \\
\text { \& Wood, J. J. (2013). Intensive cognitive behavioral therapy for anxiety } \\
\text { disorders in school-aged children with autism: A preliminary comparison } \\
\text { with treatment-as-usual. School Mental Health, 5(1), 25-37. doi: } \\
\text { 10.1007/s12310-012-9090-0 }\end{array}$ & $\begin{array}{l}\text { No post } \\
\text { treatment free } \\
\text { from all anxiety } \\
\text { diagnoses data }\end{array}$ \\
\hline $\begin{array}{l}\text { Galla, B. M., Wood, J. J., Chiu, A. W., Langer, D. A., Jacobs, J., } \\
\text { Ifekwunigwe, M., \& Larkins, C. (2012). One year follow-up to modular } \\
\text { cognitive behavioral therapy for the treatment of pediatric anxiety } \\
\text { disorders in an elementary school setting. Child Psychiatry \& Human } \\
\text { Development, 43(2), 219-226. doi: 10.1007/s10578-011-0258-x }\end{array}$ & $\begin{array}{l}\text { No non-CBT } \\
\text { control (Follow } \\
\text { up study) }\end{array}$ \\
\hline $\begin{array}{l}\text { Gallagher, H. M., Rabian, B. A., \& McCloskey, M. S. (2004). A brief } \\
\text { group cognitive-behavioral intervention for social phobia in childhood. } \\
\text { Journal of Anxiety Disorders, 18(4), 459-479. doi: 10.1016/s0887- } \\
6185(03) 00027-6\end{array}$ & $\begin{array}{l}\text { No post } \\
\text { treatment free } \\
\text { from all anxiety } \\
\text { diagnoses data }\end{array}$ \\
\hline $\begin{array}{l}\text { Gallo, K. P., Chan, P. T., Buzzella, B. A., Whitton, S. W., \& Pincus, D. B. } \\
\text { (2012). The impact of an 8-day intensive treatment for adolescent panic } \\
\text { disorder and agoraphobia on comorbid diagnoses. Behavior Therapy, } \\
\text { 43(1), 153-159. doi: } 10.1016 / \text { j.beth.2011.05.002 }\end{array}$ & $\begin{array}{l}\text { No post } \\
\text { treatment free } \\
\text { from all anxiety } \\
\text { diagnoses data }\end{array}$ \\
\hline $\begin{array}{l}\text { Garcia-Lopez, L. J., Díaz-Castela, M. d. M., Muela-Martinez, J. A., \& } \\
\text { Espinosa-Fernandez, L. (2014). Can parent training for parents with high } \\
\text { levels of expressed emotion have a positive effect on their child's social } \\
\text { anxiety improvement? Journal of Anxiety Disorders, 28(8), 812-822. doi: } \\
\text { 10.1016/j.janxdis.2014.09.001 }\end{array}$ & $\begin{array}{l}\text { No non-CBT } \\
\text { control }\end{array}$ \\
\hline $\begin{array}{l}\text { Gil-Bernal, F., \& Hernández-Guzmán, L. (2009). Cognitive-behavioural } \\
\text { treatment in Mexican children with social phobia. Anuario de } \\
\text { Psicología/The UB Journal of Psychology, 40(1), 89-104. }\end{array}$ & $\begin{array}{l}\text { No post } \\
\text { treatment free } \\
\text { from all anxiety } \\
\text { diagnoses data } \\
\end{array}$ \\
\hline $\begin{array}{l}\text { Ginsburg, G. S., Becker, E. M., Keeton, C. P., Sakolsky, D., Piacentini, J., } \\
\text { Albano, A. M., Compton, S. N.,...Caporino, N. (2014). Naturalistic } \\
\text { follow-up of youths treated for pediatric anxiety disorders. JAMA } \\
\text { Psychiatry, 71(3), 310-318. doi: 10.1001/jamapsychiatry.2013.4186 }\end{array}$ & $\begin{array}{l}\text { Participants not } \\
\text { between 4-19 }\end{array}$ \\
\hline Ginsburg, G. S., Becker, K. D., Dr & \\
\hline
\end{tabular}




\begin{tabular}{|c|c|}
\hline $\begin{array}{l}\text { Treating anxiety disorders in inner city schools: Results from a pilot } \\
\text { randomized controlled trial comparing CBT and usual care. Child \& } \\
\text { Youth Care Forum, 41(1), 1-19. doi: } 10.1007 / \mathrm{s} 10566-011-9156-4\end{array}$ & $\begin{array}{l}\text { treatment free } \\
\text { from all anxiety } \\
\text { diagnoses data }\end{array}$ \\
\hline $\begin{array}{l}\text { Goldbeck, L., \& Ellerkamp, T. (2012). A randomized controlled trial of } \\
\text { multimodal music therapy for children with anxiety disorders. Journal of } \\
\text { Music Therapy, 49(4), 395-413. doi: } 10.1093 / \mathrm{jmt} / 49.4 .395\end{array}$ & $\begin{array}{l}\text { Not CBT } \\
\text { only/based } \\
\text { treatment trial }\end{array}$ \\
\hline $\begin{array}{l}\text { Goletz, H., Yang, Y.-I., Suhr-Dachs, L., Walter, D., \& Döpfner, M. } \\
\text { (2013). Alltagswirksamkeit kognitiver Verhaltenstherapie bei Kindern } \\
\text { und Jugendlichen mit Angststörungen in einer Ausbildungsambulanz. } \\
\text { Zeitschrift für Kinder-und Jugendpsychiatrie und Psychotherapie., } 41 \text { (4), } \\
\text { 247-260 doi: 10.1024/1422-4917/a000239 }\end{array}$ & Not RCT \\
\hline $\begin{array}{l}\text { Hayward, C., Varady, S., Albano, A. M., Thienemann, M., Henderson, L., } \\
\& \text { Schatzberg, A. F. (2000). Cognitive-behavioral group therapy for social } \\
\text { phobia in female adolescents: Results of a pilot study. Journal of the } \\
\text { American Academy of Child \& Adolescent Psychiatry, 39(6), 721-726. } \\
\text { doi: 10.1097/00004583-200006000-00010 }\end{array}$ & $\begin{array}{l}\text { No post } \\
\text { treatment free } \\
\text { from all anxiety } \\
\text { diagnoses data }\end{array}$ \\
\hline $\begin{array}{l}\text { Hedman, E., Andersson, E., Ljótsson, B., Andersson, G., Schalling, M., } \\
\text { Lindefors, N., \& Rück, C. (2012). Clinical and genetic outcome } \\
\text { determinants of Internet - and group - based cognitive behavior therapy } \\
\text { for social anxiety disorder. Acta Psychiatrica Scandinavica, 126(2), 126- } \\
\text { 136. doi: } 10.1111 / \text { j.1600-0447.2012.01834.x }\end{array}$ & $\begin{array}{l}\text { Not CBT } \\
\text { only/based } \\
\text { treatment trial }\end{array}$ \\
\hline $\begin{array}{l}\text { Herbert, J. D. (2009). Cognitive behavior therapy for generalized social } \\
\text { anxiety disorder in adolescents: A randomized controlled trial. Journal of } \\
\text { Anxiety disorders, 23(2), 167-177. doi: } 10.1016 / \mathrm{j} \text {.janxdis.2008.06.004 }\end{array}$ & $\begin{array}{l}\text { No post } \\
\text { treatment free } \\
\text { from all anxiety } \\
\text { diagnoses data }\end{array}$ \\
\hline $\begin{array}{l}\text { Holmes, M. C., Donovan, C. L., Farrell, L. J., \& March, S. (2014). The } \\
\text { efficacy of a group-based, disorder-specific treatment program for } \\
\text { childhood GAD-A randomized controlled trial. Behaviour Research and } \\
\text { Therapy, 61, 122-135. doi: 10.1016/j.brat.2014.08.002 }\end{array}$ & $\begin{array}{l}\text { No post } \\
\text { treatment free } \\
\text { from all anxiety } \\
\text { diagnoses data }\end{array}$ \\
\hline $\begin{array}{l}\text { Hudson, J. L., Newall, C., Rapee, R. M., Lyneham, H. J., Schniering, C. } \\
\text { C., Wuthrich, V. M., ... \& Gar, N. S. (2014). The impact of brief parental } \\
\text { anxiety management on child anxiety treatment outcomes: a controlled } \\
\text { trial. Journal of Clinical Child \& Adolescent Psychology, 43(3), 370-380. } \\
\text { doi: 10.1080/15374416.2013.807734 }\end{array}$ & $\begin{array}{l}\text { Not CBT } \\
\text { only/based } \\
\text { treatment trial }\end{array}$ \\
\hline $\begin{array}{l}\text { Ingul, J. M., Aune, T., \& Nordahl, H. M. (2014). A randomized controlled } \\
\text { trial of individual cognitive therapy, group cognitive behaviour therapy } \\
\text { and attentional placebo for adolescent social phobia. Psychotherapy and } \\
\text { Psychosomatics, 83(1), 54-61. doi: } 10.1159 / 000354672\end{array}$ & $\begin{array}{l}\text { No post } \\
\text { treatment free } \\
\text { from all anxiety } \\
\text { diagnoses data }\end{array}$ \\
\hline $\begin{array}{l}\text { Ishikawa, S.-i., Motomura, N., Kawabata, Y., Tanaka, H., Shimotsu, S., } \\
\text { Sato, Y., \& Ollendick, T. H. (2012). Cognitive behavioural therapy for } \\
\text { Japanese children and adolescents with anxiety disorders: A pilot study. } \\
\text { Behavioural and Cognitive Psychotherapy, } 40(03), 271-285 . \text { doi: }\end{array}$ & Not RCT \\
\hline
\end{tabular}




\begin{tabular}{|c|c|}
\hline $10.1017 / \mathrm{s} 1352465811000713$ & \\
\hline $\begin{array}{l}\text { Jansen, M., van Doorn, M. M., Lichtwarck-Aschoff, A., Kuijpers, R. C., } \\
\text { Theunissen, H., Korte, M., .. Granic, I. (2012). Effectiveness of a } \\
\text { cognitive-behavioral therapy (CBT) manualized program for clinically } \\
\text { anxious children: Study protocol of a randomized controlled trial. BMC } \\
\text { Psychiatry, } 12(1), 16 \text {. doi: } 10.1186 / 1471-244 x-12-16\end{array}$ & Study protocol \\
\hline $\begin{array}{l}\text { Jarrett, M. A., \& Ollendick, T. H. (2012). Treatment of comorbid } \\
\text { attention-deficit/hyperactivity disorder and anxiety in children: A multiple } \\
\text { baseline design analysis. Journal of Consulting and Clinical Psychology, } \\
80(2), 239 . \text { doi: } 10.1037 / \text { a0027123 }\end{array}$ & $\begin{array}{l}\text { Not CBT } \\
\text { only/based } \\
\text { treatment trial }\end{array}$ \\
\hline $\begin{array}{l}\text { Jongerden, L., \& Bögels, S. M. (2014). Parenting, family functioning and } \\
\text { anxiety-disordered children: comparisons to controls, changes after family } \\
\text { versus child CBT. Journal of Child and Family Studies, 1-14. doi: } \\
\text { 10.1007/s10826-014-0005-6 }\end{array}$ & $\begin{array}{l}\text { No-non-CBT } \\
\text { control }\end{array}$ \\
\hline $\begin{array}{l}\text { Kendall, P. C. (1994). Treating anxiety disorders in children: Results of a } \\
\text { randomized clinical trial. Journal of Consulting and Clinical Psychology, } \\
62(1), 100-110 \text {. doi: 10.1037//0022-006x.62.1.100 }\end{array}$ & $\begin{array}{l}\text { No post } \\
\text { treatment free } \\
\text { from all anxiety } \\
\text { diagnoses data }\end{array}$ \\
\hline $\begin{array}{l}\text { Kendall, P. C., Flannery-Schroeder, E., Panichelli-Mindel, S. M., } \\
\text { Southam-Gerow, M., Henin, A., \& Warman, M. (1997). Therapy for } \\
\text { youths with anxiety disorders: A second randomized clincal trial. Journal } \\
\text { of Consulting and Clinical Psychology, 65(3), 366. doi: 10.1037//0022- } \\
\text { 006x.65.3.366 }\end{array}$ & $\begin{array}{l}\text { No post } \\
\text { treatment free } \\
\text { from all anxiety } \\
\text { diagnoses data }\end{array}$ \\
\hline $\begin{array}{l}\text { Kendall, P. C., Hudson, J. L., Gosch, E., Flannery-Schroeder, E., \& } \\
\text { Suveg, C. (2008). Cognitive-behavioral therapy for anxiety disordered } \\
\text { youth: a randomized clinical trial evaluating child and family modalities. } \\
\text { Journal of Consulting and Clinical Psychology, } 76(2), 282 . \text { doi: } \\
\text { 10.1037/0022-006x.76.2.282 }\end{array}$ & $\begin{array}{l}\text { No post } \\
\text { treatment free } \\
\text { from all anxiety } \\
\text { diagnoses data }\end{array}$ \\
\hline $\begin{array}{l}\text { Kerns, C. M., Read, K. L., Klugman, J., \& Kendall, P. C. (2013). } \\
\text { Cognitive behavioral therapy for youth with social anxiety: Differential } \\
\text { short and long-term treatment outcomes. Journal of Anxiety Disorders, } \\
\text { 27(2), 210-215. doi: } 10.1016 / \text { j.janxdis.2013.01.009 }\end{array}$ & Duplicate study \\
\hline $\begin{array}{l}\text { Langdon, P. E., Murphy, G. H., Wilson, E., Shepstone, L., Fowler, D., } \\
\text { Heavens, D., .. Russell, A. (2013). Asperger syndrome and anxiety } \\
\text { disorders (PAsSA) treatment trial: A study protocol of a pilot, } \\
\text { multicentre, single-blind, randomised crossover trial of group cognitive } \\
\text { behavioural therapy. BMJ open, 3(7), e003449. doi: 10.1136/bmjopen- } \\
\text { 2013-003449 }\end{array}$ & Study protocol \\
\hline $\begin{array}{l}\text { Lau, J. Y., Belli, S. R., \& Chopra, R. B. (2013). Cognitive bias } \\
\text { modification training in adolescents reduces anxiety to a psychological } \\
\text { challenge. Clinical Child Psychology and Psychiatry, 18(3), 322-333. doi: } \\
10.1177 / 1359104512455183\end{array}$ & $\begin{array}{l}\text { Not CBT } \\
\text { only/based } \\
\text { treatment trial }\end{array}$ \\
\hline
\end{tabular}




\begin{tabular}{|c|c|}
\hline $\begin{array}{l}\text { Lau, W.-y., Chan, C. K.-y., Li, J. C.-h., \& Au, T. K.-f. (2010). } \\
\text { Effectiveness of group cognitive-behavioral treatment for childhood } \\
\text { anxiety in community clinics. Behaviour Research and Therapy, 48(11), } \\
\text { 1067-1077. doi: } 10.5353 / \text { th_b4171251 }\end{array}$ & $\begin{array}{l}\text { No post } \\
\text { treatment free } \\
\text { from all anxiety } \\
\text { diagnoses data }\end{array}$ \\
\hline $\begin{array}{l}\text { Lebowitz, E. R., Omer, H., Hermes, H., \& Scahill, L. (2014). Parent } \\
\text { training for childhood anxiety disorders: the SPACE program. Cognitive } \\
\text { and Behavioral Practice, 21(4), 456-469. 10.1016/j.cbpra.2013.10.004 }\end{array}$ & Not RCT \\
\hline $\begin{array}{l}\text { Lehenbauer, M., Kothgassner, O. D., Kryspin-Exner, I., \& Stetina, B. U. } \\
\text { (2013). An online self-administered social skills training for young adults: } \\
\text { Results from a pilot study. Computers \& Education, 61, 217-224. doi: } \\
\text { 10.1016/j.compedu.2012.09.007 }\end{array}$ & $\begin{array}{l}\text { Not CBT } \\
\text { only/based } \\
\text { treatment trial }\end{array}$ \\
\hline $\begin{array}{l}\text { Marriage, D., \& Henderson, J. (2012). Cognitive behaviour therapy for } \\
\text { anxiety in children with asthma: Deborah Marriage and John Henderson } \\
\text { explore how nurses can help patients use psychological therapy to cope } \\
\text { with asthma-related anxiety. Nursing children and young people, } 24(9) \text {, } \\
\text { 30-34. doi: } 10.7748 / \text { ncyp2012.11.24.9.30.c9392 }\end{array}$ & $\begin{array}{l}\text { No diagnostic } \\
\text { measures used }\end{array}$ \\
\hline $\begin{array}{l}\text { Masia Warner, C., Colognori, D., Kim, R. E., Reigada, L. C., Klein, R. } \\
\text { G., Browner-Elhanan, ... Chhabra, M. (2011). Cognitive-behavioral } \\
\text { treatment of persistent functional somatic complaints and pediatric } \\
\text { anxiety: An initial controlled trial. Depression and Anxiety, 28(7), 551- } \\
\text { 559. doi: } 10.1002 / \text { da.20821 }\end{array}$ & $\begin{array}{l}\text { No post } \\
\text { treatment free } \\
\text { from all anxiety } \\
\text { diagnoses data }\end{array}$ \\
\hline $\begin{array}{l}\text { Masia-Warner, C., Klein, R. G., Dent, H. C., Fisher, P. H., Alvir, J., } \\
\text { Albano, A. M., \& Guardino, M. (2005). School-based intervention for } \\
\text { adolescents with social anxiety disorder: Results of a controlled study. } \\
\text { Journal of Abnormal Child Psychology, 33(6), 707-722. doi: } \\
\text { 10.1007/s10802-005-7649-z }\end{array}$ & $\begin{array}{l}\text { No post } \\
\text { treatment free } \\
\text { from all anxiety } \\
\text { diagnoses data }\end{array}$ \\
\hline $\begin{array}{l}\text { McGillivray, J., \& Evert, H. (2014). Group cognitive behavioural therapy } \\
\text { program shows potential in reducing symptoms of depression and stress } \\
\text { among young people with ASD. Journal of Autism and Developmental } \\
\text { Disorders, 44(8), 2041-2051. doi: } 10.1007 / \text { s10803-014-2087-9 }\end{array}$ & $\begin{array}{l}\text { No post- } \\
\text { treatment } \\
\text { diagnostic data }\end{array}$ \\
\hline $\begin{array}{l}\text { McNally-Keehn, R. H., Lincoln, A. J., Brown, M. Z., \& Chavira, D. A. } \\
\text { (2013). The coping cat program for children with anxiety and autism } \\
\text { spectrum disorder: a pilot randomized controlled trial. Journal of Autism } \\
\text { and Developmental Disorders, 43(1), 57-67. doi: } 10.1007 / \text { s10803-012- } \\
\text { 1541-9 }\end{array}$ & $\begin{array}{l}\text { No post } \\
\text { treatment free } \\
\text { from all anxiety } \\
\text { diagnoses data }\end{array}$ \\
\hline $\begin{array}{l}\text { Melfsen, S., Kühnemund, M., Schwieger, J., Warnke, A., Stadler, C., } \\
\text { Poustka, F., \& Stangier, U. (2011). Cognitive behavioral therapy of } \\
\text { socially phobic children focusing on cognition: A randomised wait-list } \\
\text { control study. Child and Adolescent Psychiatry and Mental Health, 5(5), } \\
\text { 1-12. doi: 10.1186/1753-2000-5-5 }\end{array}$ & $\begin{array}{l}\text { No post } \\
\text { treatment free } \\
\text { from all anxiety } \\
\text { diagnoses data }\end{array}$ \\
\hline $\begin{array}{l}\text { Mendlowitz, S. L., Manassis, K., Bradley, S., Scapillato, D., Miezi } \\
\text { \& Shaw, B. E. (1999). Cognitive-behavioral group treatments in }\end{array}$ & Not RCT \\
\hline
\end{tabular}




\begin{tabular}{|c|c|}
\hline $\begin{array}{l}\text { childhood anxiety disorders: The role of parental involvement. Journal of } \\
\text { the American Academy of Child and Adolescent Psychiatry, 38(10), 1223- } \\
\text { 1229. doi: 10.1097/00004583-199910000-00010 }\end{array}$ & \\
\hline $\begin{array}{l}\text { Monga, S., Rosenbloom, B. N., Tanha, A., Owens, M., \& Young, A. } \\
\text { (2015). Comparison of child-parent and parent-only cognitive-behavioral } \\
\text { therapy programs for anxious children aged } 5 \text { to } 7 \text { Years: short-and long- } \\
\text { term outcomes. Journal of the American Academy of Child \& Adolescent } \\
\text { Psychiatry, 54(2), 138-146. doi: } 10.1016 / \mathrm{j} . j a a c .2014 .10 .008\end{array}$ & Not RCT \\
\hline $\begin{array}{l}\text { Motoca, L. M. (2012). Treatment Moderation and Secondary Outcomes: } \\
\text { Results from a Randomized Clinical Trial. }\end{array}$ & $\begin{array}{l}\text { No non-CBT } \\
\text { control }\end{array}$ \\
\hline $\begin{array}{l}\text { Muris, P., Meesters, C., \& van Melick, M. (2002). Treatment of childhood } \\
\text { anxiety disorders: A preliminary comparison between cognitive- } \\
\text { behavioral group therapy and a psychological placebo intervention. } \\
\text { Journal of Behavior Therapy and Experimental Psychiatry, 33(3), 143- } \\
\text { 158. doi: } 10.1016 / \mathrm{s} 0005-7916(02) 00025-3\end{array}$ & $\begin{array}{l}\text { No post- } \\
\text { treatment } \\
\text { diagnostic data }\end{array}$ \\
\hline $\begin{array}{l}\text { Nauta, M. H., Scholing, A., Emmelkamp, P. M., \& Minderaa, R. B. } \\
\text { (2003). Cognitive-behavioral therapy for children with anxiety disorders } \\
\text { in a clinical setting: No additional effect of a cognitive parent training. } \\
\text { Journal of the American Academy of Child \& Adolescent Psychiatry, } \\
\text { 42(11), 1270-1278. doi: 10.1097/01.chi.0000085752.71002.93 }\end{array}$ & Not RCT \\
\hline $\begin{array}{l}\text { Nauta, M. H., Festen, H., Reichart, C. G., Nolen, W. A., Stant, A. D., } \\
\text { Bockting, C. L.,... Hartman, C. A. (2012). Preventing mood and anxiety } \\
\text { disorders in youth: a multi-centre RCT in the high risk offspring of } \\
\text { depressed and anxious patients. BMC Psychiatry, 12(1), 31. doi: } \\
\text { 10.1186/1471-244x-12-31 }\end{array}$ & Study protocol \\
\hline $\begin{array}{l}\text { Olivares, J., Olivares-Olivares, P. J., \& Macià, D. (2014). Entrenamiento } \\
\text { en habilidades sociales y tratamiento de adolescentes con fobia social } \\
\text { generalizada. Psicología Conductual, 22(3), 441= 459. }\end{array}$ & $\begin{array}{l}\text { No non-CBT } \\
\text { control }\end{array}$ \\
\hline $\begin{array}{l}\text { Olivares-Rodríguez, J., Alcázar, A. I. R., \& Rodríguez, J. A. P. (2005). } \\
\text { Detección temprana y tratamiento de adolescentes con fobia social } \\
\text { generalizada. Psicothema, 17(1), 1-8. }\end{array}$ & $\begin{array}{l}\text { No post } \\
\text { treatment free } \\
\text { from all anxiety } \\
\text { diagnoses data }\end{array}$ \\
\hline $\begin{array}{l}\text { Ollendick, T. H., Halldorsdottir, T., Fraire, M. G., Austin, K. E., Noguchi, } \\
\text { R. J., Lewis, K. M., Jarrett, M. A., Cunningham, N. R., Canavera, K., \& } \\
\text { Allen, K. B. (2015). Specific phobias in youth: A randomized controlled } \\
\text { trial comparing one-session treatment to a parent-augmented one-session } \\
\text { treatment. Behavior Therapy, 46(2), 141-155. doi: } \\
\text { 10.1016/j.beth.2014.09.004 }\end{array}$ & $\begin{array}{l}\text { Specific phobia } \\
\text { treatment only }\end{array}$ \\
\hline $\begin{array}{l}\text { Pereira, A. I., Marques, T., Russo, V., Barros, L., \& Barrett, P. (2014). } \\
\text { Effectiveness of the FRIENDS for life program in Portuguese schools: }\end{array}$ & $\begin{array}{l}\text { No post } \\
\text { treatment }\end{array}$ \\
\hline
\end{tabular}




\begin{tabular}{|c|c|}
\hline $\begin{array}{l}\text { Study with a sample of highly anxious children. Psychology in the } \\
\text { Schools, 51(6), 647-657. doi: } 10.1002 / \text { pits. } 21767\end{array}$ & diagnostic data \\
\hline $\begin{array}{l}\text { Piacentini, J., Bennett, S., Compton, S., Kendall, P. C., Birmaher, B., } \\
\text { Albano, A. M., ...Walkup, J. (2014). 24- and 36-Week Outcomes for the } \\
\text { Child/Adolescent Anxiety Multimodal Study (CAMS). Journal of the } \\
\text { American Academy of Child \& Adolescent } \\
\text {,53(3), 297-310. doi: } 10.1016 / \text { j.jaac.2013.11.010 }\end{array}$ & $\begin{array}{l}\text { No post } \\
\text { treatment free } \\
\text { from all anxiety } \\
\text { diagnoses data }\end{array}$ \\
\hline $\begin{array}{l}\text { Pina, A. A., Zerr, A. A., Villalta, I. K., \& Gonzales, N. A. (2012). } \\
\text { Indicated prevention and early intervention for childhood anxiety: A } \\
\text { randomized trial with Caucasian and Hispanic/Latino youth. Journal of } \\
\text { Consulting and Clinical Psychology, 80(5), 940. doi: 10.1037/a0029460 }\end{array}$ & Not RCT \\
\hline $\begin{array}{l}\text { Reuland, M. M., \& Teachman, B. A. (2014). Interpretation bias } \\
\text { modification for youth and their parents: A novel treatment for early } \\
\text { adolescent social anxiety. Journal of Anxiety Disorders, 28(8), 851-864. } \\
\text { doi: } 10.1016 / \text { j.janxdis.2014.09.011 }\end{array}$ & $\begin{array}{l}\text { No non-CBT } \\
\text { control }\end{array}$ \\
\hline $\begin{array}{l}\text { Rodgers, A., \& Dunsmuir, S. (2015). A controlled evaluation of the } \\
\text { 'FRIENDS for Life'emotional resiliency programme on overall anxiety } \\
\text { levels, anxiety subtype levels and school adjustment. Child and } \\
\text { Adolescent Mental Health, } 20 \text { (1), } 13 \text { - 19. doi: } 10.1111 / \text { camh. } 12030\end{array}$ & $\begin{array}{l}\text { No post } \\
\text { treatment } \\
\text { diagnostic data }\end{array}$ \\
\hline $\begin{array}{l}\text { Rosa-Alcázar, A. I., Boix, M. A., \& Olivares-Olivares, P. J. (2013). } \\
\text { Aportaciones de la reestructuración cognitiva en el tratamiento de la fobia } \\
\text { social generalizada en adolescentes. Psicología Conductual, 21(1), 5. }\end{array}$ & $\begin{array}{l}\text { No non-CBT } \\
\text { control }\end{array}$ \\
\hline $\begin{array}{l}\text { Ryan, N. D. (2014). Treating anxiety in youth: does maintenance } \\
\text { treatment maintain? Journal of American Academy of Child \& Adolescent } \\
\text { Psychiatry, 3(53), 269-270. doi: 10.1016/j.jaac.2013.11.008 }\end{array}$ & $\begin{array}{l}\text { Duplicate study, } \\
\text { editorial of study }\end{array}$ \\
\hline $\begin{array}{l}\text { Sánchez-García, R., \& Rodríguez, J. O. (2009). Effectiveness of a } \\
\text { program for early detection/intervention in children/adolescents with } \\
\text { generalized social phobia. Anales De Psicologia, 25(2), 241-249. }\end{array}$ & $\begin{array}{l}\text { No post } \\
\text { treatment free } \\
\text { from all anxiety } \\
\text { diagnoses data }\end{array}$ \\
\hline $\begin{array}{l}\text { Santucci, L. C., \& Ehrenreich-May, J. (2013). A randomized controlled } \\
\text { trial of the child anxiety multi-day program (CAMP) for separation } \\
\text { anxiety disorder. Child Psychiatry \& Human Development, 44(3), 439- } \\
\text { 451. doi: } 10.1007 / \mathrm{s} 10578-012-0338-6\end{array}$ & $\begin{array}{l}\text { No post } \\
\text { treatment free } \\
\text { from all anxiety } \\
\text { diagnoses data }\end{array}$ \\
\hline $\begin{array}{l}\text { Settipani, C. A., \& Kendall, P. C. (2013). Social functioning in youth with } \\
\text { anxiety disorders: Association with anxiety severity and outcomes from } \\
\text { cognitive-behavioral therapy. Child Psychiatry \& Human Development, } \\
\text { 44(1), 1-18. doi: } 10.1007 / \text { s10578-012-0307-0 }\end{array}$ & Duplicate study \\
\hline $\begin{array}{l}\text { Shechner, T., Rimon-Chakir, A., Britton, J. C., Lotan, D., Apter, A., } \\
\text { Bliese, P. D., . . Bar-Haim, Y. (2014). Attention bias modification } \\
\text { treatment augmenting effects on cognitive behavioral therapy in children } \\
\text { with anxiety: randomized controlled trial. Journal of the American } \\
\text { Academy of Child \& Adolescent Psychiatry, 53(1), 61-71. doi: } \\
\text { 10.1016/j.jaac.2013.09.016 }\end{array}$ & $\begin{array}{l}\text { Not CBT based } \\
\text { treatment trial }\end{array}$ \\
\hline
\end{tabular}




\begin{tabular}{|c|c|}
\hline $\begin{array}{l}\text { Schneider, S., Blatter-Meunier, J., Herren, C., In-Albon, T., Adornetto, } \\
\text { C., Meyer, A., \& Lavallee, K. L. (2013). The efficacy of a family-based } \\
\text { cognitive-behavioral treatment for separation anxiety disorder in children } \\
\text { aged 8-13: A randomized comparison with a general anxiety program. } \\
\text { Journal of Consulting and Clinical Psychology, 81(5), 932. doi: } \\
\text { 10.1037/a0032678 }\end{array}$ & $\begin{array}{l}\text { No post } \\
\text { treatment free } \\
\text { from all anxiety } \\
\text { diagnoses data }\end{array}$ \\
\hline $\begin{array}{l}\text { Schneider, S., Blatter-Meunier, J., Herren, C., Adornetto, C., In-Albon, } \\
\text { T., \& Lavallee, K. (2011). Disorder-specific cognitive-behavioral therapy } \\
\text { for separation anxiety disorder in young children: A randomized waiting- } \\
\text { list-controlled trial. Psychotherapy and Psychosomatics, } 80(4), 206 . \text { doi: } \\
\text { 10.1159/000323444 }\end{array}$ & $\begin{array}{l}\text { No post } \\
\text { treatment free } \\
\text { from all anxiety } \\
\text { diagnoses data }\end{array}$ \\
\hline $\begin{array}{l}\text { Silverman, W. K., Kurtines, W. M., Ginsburg, G. S., Weems, C. F., } \\
\text { Lumpkin, P. W., \& Carmichael, D. H. (1999). Treating anxiety disorders } \\
\text { in children with group cognitive-behavioral therapy: A randomized } \\
\text { clinical trial. Journal of Consulting and Clinical Psychology, 67(6), } 995 . \\
\text { doi: 10.1037/0022-006x.67.6.995 }\end{array}$ & $\begin{array}{l}\text { No post } \\
\text { treatment free } \\
\text { from all anxiety } \\
\text { diagnoses data }\end{array}$ \\
\hline $\begin{array}{l}\text { Smith, A. M., Flannery-Schroeder, E. C., Gorman, K. S., \& Cook, N. } \\
\text { (2014). Parent cognitive-behavioral intervention for the treatment of } \\
\text { childhood anxiety disorders: A pilot study. Behaviour Research and } \\
\text { Therapy, 61, 156-161. doi: 10.1016/j.brat.2014.08.010 }\end{array}$ & $\begin{array}{l}\text { No direct child } \\
\text { contact }\end{array}$ \\
\hline $\begin{array}{l}\text { Spence, S. H., Donovan, C. L., \& Brechman-Toussaint, M. (2000). The } \\
\text { treatment of childhood social phobia: The effectiveness of a social skills } \\
\text { training-based, cognitive-behavioural intervention, with and without } \\
\text { parental involvement. Journal of Child Psychology and Psychiatry, 41(6), } \\
\text { 713-726. doi: 10.1017/s0021963099005934 }\end{array}$ & $\begin{array}{l}\text { No post } \\
\text { treatment free } \\
\text { from all anxiety } \\
\text { diagnoses data }\end{array}$ \\
\hline $\begin{array}{l}\text { Sportel, B. E., de Hullu, E., de Jong, P. J., \& Nauta, M. H. (2013). } \\
\text { Cognitive bias modification versus CBT in reducing adolescent social } \\
\text { anxiety: a randomized controlled trial. PloS one, 8(5), e64355. doi: } \\
\text { 10.1371/journal.pone.0064355 }\end{array}$ & $\begin{array}{l}\text { Participants did } \\
\text { not all meet } \\
\text { diagnostic } \\
\text { criteria }\end{array}$ \\
\hline $\begin{array}{l}\text { Stallard, P., Taylor, G., Anderson, R., Daniels, H., Simpson, N., Phillips, } \\
\text { R., \& Skryabina, E. (2012). School-based intervention to reduce anxiety } \\
\text { in children: Study protocol for a randomized controlled trial (PACES). } \\
\text { Trials, 13(1), 227-227. doi: } 10.1186 / 1745-6215-13-227\end{array}$ & Study protocol \\
\hline
\end{tabular}




\begin{tabular}{|c|c|}
\hline $\begin{array}{l}\text { Sung, M., Ooi, Y. P., Goh, T. J., Pathy, P., Fung, D. S., Ang, R. P., Chua, } \\
\text { A., \& Lam, C. M. (2011). Effects of cognitive-behavioral therapy on } \\
\text { anxiety in children with autism spectrum disorders: A randomized } \\
\text { controlled trial. Child Psychiatry \& Human Development, 42(6), 634-649. } \\
\text { doi: 10.1007/s10578-011-0238-1 }\end{array}$ & $\begin{array}{l}\text { No diagnostic } \\
\text { measures used }\end{array}$ \\
\hline $\begin{array}{l}\text { Utens, E. (2012). S. } 05.03 \text { Early intervention. European } \\
\text { Neuropsychopharmacology, 22, S119-S120. doi: 10.1016/s0924- } \\
977 x(12) 70132-3\end{array}$ & Duplicate study \\
\hline $\begin{array}{l}\text { Van Starrenburg, M. L., Kuijpers, R. C., Hutschemaekers, G. J., \& } \\
\text { Engels, R. C. (2013). Effectiveness and underlying mechanisms of a } \\
\text { group-based cognitive behavioural therapy-based indicative prevention } \\
\text { program for children with elevated anxiety levels. BMC Psychiatry, 13(1), } \\
\text { 183. doi: } 10.1186 / 1471-244 x-13-183\end{array}$ & Study protocol \\
\hline $\begin{array}{l}\text { Walkup, J. T., Albano, A. M., Piacentini, J., Birmaher, B., Compton, S. } \\
\text { N., Sherrill, J. T., Ginsburg, G. S., Rynn, M. A., McCracken, J., \& } \\
\text { Waslick, B. (2008). Cognitive behavioral therapy, sertraline, or a } \\
\text { combination in childhood anxiety. New England Journal of Medicine, } \\
\text { 359(26), 2753-2766. doi: 10.1056/NEJMoa0804633 }\end{array}$ & $\begin{array}{l}\text { No post- } \\
\text { treatment } \\
\text { diagnostic data }\end{array}$ \\
\hline $\begin{array}{l}\text { Walter, D., Hautmann, C., Rizk, S., Lehmkuhl, G., \& Doepfner, M. } \\
\text { (2014). Short-and Long-Term Effects of Inpatient Cognitive-Behavioral } \\
\text { Treatment of Adolescents With Anxious-Depressed School Absenteeism: } \\
\text { A Within-Subject Comparison of Changes. Child \& Family Behavior } \\
\text { Therapy, 36(3), 171-190. doi: 10.1080/07317107.2014.934173 }\end{array}$ & Not RCT \\
\hline $\begin{array}{l}\text { Watson, C. C., Rich, B. A., Sanchez, L., O’Brien, K., \& Alvord, M. K. } \\
\text { (2014). Preliminary study of resilience-based group therapy for improving } \\
\text { the functioning of anxious children. Child \& Youth Care Forum, } 43 \text { (3), } \\
\text { 269-286. doi: } 10.1007 / \mathrm{s} 10566-013-9238-6\end{array}$ & Not RCT \\
\hline $\begin{array}{l}\text { Weisz, J. R., Chorpita, B. F., Palinkas, L. A., Schoenwald, S. K., Miranda, } \\
\text { J., Bearman, S. K... Martin, J. (2012). Testing standard and modular } \\
\text { designs for psychotherapy treating depression, anxiety, and conduct } \\
\text { problems in youth: A randomized effectiveness trial. Archives of General } \\
\text { Psychiatry, 69(3), 274-282. doi: 10.1001/archgenpsychiatry.2011.147 }\end{array}$ & $\begin{array}{l}\text { Other disorder } \\
\text { treatment study }\end{array}$ \\
\hline $\begin{array}{l}\text { Wergeland, G. J. H., Fjermestad, K. W., Marin, C. E., Haugland, B. S.- } \\
\text { M., Bjaastad, J. F., Oeding, K., ...Havik, O. E. (2014). An effectiveness } \\
\text { study of individual vs. group cognitive behavioral therapy for anxiety } \\
\text { disorders in youth. Behaviour Research and Therapy, 57, 1-12. doi: } \\
\text { 10.1016/j.brat.2014.03.007 }\end{array}$ & $\begin{array}{l}\text { No post } \\
\text { treatment free } \\
\text { from all anxiety } \\
\text { diagnoses data }\end{array}$ \\
\hline $\begin{array}{l}\text { White, S. W., Ollendick, T., Albano, A. M., Oswald, D., Johnson, C., } \\
\text { Southam-Gerow, M. A., Kim, I., \& Scahill, L. (2013). Randomized } \\
\text { controlled trial: Multimodal anxiety and social skill intervention for } \\
\text { adolescents with autism spectrum disorder. Journal of Autism and } \\
\text { Developmental Disorders, 43(2), 382-394. doi: 10.1007/s10803-012- } \\
\text { 1577-x }\end{array}$ & $\begin{array}{l}\text { No post } \\
\text { treatment } \\
\text { diagnostic data }\end{array}$ \\
\hline Wong, N., Kady, L., Mewton, L., Sund & No post \\
\hline
\end{tabular}




\begin{tabular}{|l|l|}
\hline $\begin{array}{l}\text { Preventing anxiety and depression in adolescents: A randomised } \\
\text { controlled trial of two school based Internet-delivered cognitive } \\
\text { behavioural therapy programmes. Internet Interventions, 1(2), 90-94. doi: } \\
\text { 10.1016/j.invent.2014.05.004 }\end{array}$ & $\begin{array}{l}\text { treatment } \\
\text { diagnostic data }\end{array}$ \\
\hline $\begin{array}{l}\text { Wood, J. J., Drahota, A., Sze, K., Har, K., Chiu, A., \& Langer, D. A. } \\
\text { (2009). Cognitive behavioral therapy for anxiety in children with autism } \\
\text { spectrum disorders: A randomized, controlled trial. Journal of Child } \\
\text { Psychology and Psychiatry, 50(3), 224-234. doi: 10.1111/j.1469- } \\
\text { 7610.2008.01948.X }\end{array}$ & $\begin{array}{l}\text { No post } \\
\text { treatment free } \\
\text { from all anxiety } \\
\text { diagnoses data }\end{array}$ \\
\hline $\begin{array}{l}\text { Wood, J. J., Ehrenreich-May, J., Alessandri, M., Fujii, C., Renno, P., } \\
\text { Laugeson, E., ... Lewin, A. B. (2015). Cognitive behavioral therapy for } \\
\text { early adolescents with autism spectrum disorders and clinical anxiety: a } \\
\text { randomized, controlled trial. Behavior Therapy, 46(1), 7-19. doi: } \\
\text { 10.1016/j.beth.2014.01.002 }\end{array}$ & $\begin{array}{l}\text { No post } \\
\text { treatment free } \\
\text { from all anxiety } \\
\text { diagnoses data }\end{array}$ \\
\hline $\begin{array}{l}\text { Wu, X., Liu, F., Cai, H., Huang, L., Li, Y., Mo, Z., \& Lin, J. (2013). } \\
\text { Cognitive behaviour therapy combined fluoxetine treatment superior to } \\
\text { cognitive behaviour therapy alone for school refusal. International } \\
\text { Journal of Pharmacology, 9(3), 197-203. doi: 10.3923/ijp.2013.197.203 }\end{array}$ & $\begin{array}{l}\text { Other disorder } \\
\text { treatment study }\end{array}$ \\
\hline $\begin{array}{l}\text { Wuthrich, V. M., Rapee, R. M., Cunningham, M. J., Lyneham, H. J., } \\
\text { Hudson, J. L., \& Schniering, C. A. (2012). A randomized controlled trial } \\
\text { of the Cool Teens CD-ROM computerized program for adolescent } \\
\text { anxiety. Journal of the American Academy of Child \& Adolescent } \\
\text { Psychiatry, 51(3), 261-270. doi: 10.1016/j.jaac.2011.12.002 }\end{array}$ & $\begin{array}{l}\text { No direct child } \\
\text { contact }\end{array}$ \\
\hline $\begin{array}{l}\text { Yen, C.-F., Chen, Y.-M., Cheng, J.-W., Liu, T.-L., Huang, T.-Y., Wang, } \\
\text { P.-W., . Chou, W.-J. (2014). Effects of cognitive-behavioral therapy on } \\
\text { Taiwanese children with anxiety disorders and their mothers. Child }\end{array}$ & Not RCT \\
013-0403-9 & \\
\hline
\end{tabular}

